\section{Kastamonu Eğitim Dergisi Kastamonu Education Journal}

Mart 2019 Cilt:27 Sayı:2

kefdergi.kastamonu.edu.tr
Başvuru Tarihi/Received: 26.05.2018

Kabul Tarihi/Accepted: 04.01.2019 DOI: 10.24106/kefdergi.3115

\title{
Öğretmenler Ne Zaman ve Nasıl Yetkin Bir Uzman Olurlar: Coğrafya Öğretmenleri Örneği
}

\section{When and How Teachers Become Competent Experts: Case of Geography Teachers}

\section{Öz}

\author{
Mustafa ÖZTÜRK' ${ }^{1}$, Hasan GÖNÜLAÇAR ${ }^{2}$
}

Öğretmenler mesleki yaşantılarına benzer şartlarda; acemi (novice) bir şekilde başlarlar. Ancak yetkin bir uzmanlığa ulaşmak her öğretmen için mümkün olmayabilir. Bu çalışmada coğrafya öğretmenleri örneğinden hareketle, Türkiyesde öğretmenlerin yetkin uzman olma süreci; buna bağlı olarak ilerleyen kariyer gelişimleri ve bu süreçte mesleklerini nasıl öğrendikleri irdelenmiştir. Çalışmaya Türkiye'nin farklı illerinde ve farklı lise türlerinde görev yapan, hizmet süresi on beş yıl ve üzeri olan toplam yirmi beş coğrafya öğretmeni katılmıştr. Çalışmada veri, yarı-yapılandırılmış görüşme tekniği ile toplanmış ve QDA Miner Lite 2.0.5 nitel analiz programıyla içerik analizine tabi tutulmuştur. Elde edilen bulgulara göre, katlımcıların birçoğunun mesleğe çok kolay bir başlangıç yapmadıkları, öğretmenliği temel olarak rol model aldıkları eski bir öğretmenlerinden ve kendi deneyimlerinden hareketle öğrendikleri belirlenmiştir. Katılımcıların mesleki gelişimlerine yönelik motivasyonlarının genellikle düşük olduğu ve mesleki gelişimleri bakımından farklı paydaşlardan yeterli desteği görmedikleri ortaya çıkmaktadır. Katılımcıların çalışmada betimlendiği şekilde yetkin uzmanlığın ölçütlerini tam olarak karşılamadıkları ancak hâlihazırda şu üç kariyer aşamasına yönelik yetkinliklere sahip oldukları anlaşımaktadır: Acemilik dönemi, uzmanlığa geçiş dönemi ve uzmanlık dönemi.

Anahtar Kelimeler: Coğrafya öğretmenleri, kariyer gelişimi, profesyonelleşme, yetkin uzmanlık.

\section{Abstract}

Teachers start their professional careers in similar conditions, as novice teachers. However, not every teacher attains the level of competent expertise in their professional lives. In this study, teachers' process of being competent professionals; their career developments and how they learn the profession during their careers are examined in the case of geography teachers in Turkey. 25 geography teachers working in different school types across Turkey participated in the study. The data was collected through semi-structured interviews. Content analysis was carried out by using QDA Miner Lite 2.0.5 qualitative analysis software. According to the results of the study, it was found that the majority of the participants did not make an easy induction to the profession and they generally learned about their profession from their role models (i.e. teachers from their own school years) and through their own experiences. Furthermore, the participants' motivations for professional development are usually low and their professional development is generally not supported by different stakeholders. It appeared that the participants have usually not meet the criteria required for the level of competent professionalism fully. However, they seemed to have competencies regarding three career stages: Novitiate, transition to expertise, expertise.

Keywords: Career development, competent expertise, geography teachers, professionalism.

1. Erciyes Üniversitesi, Eğitim Fakültesi, Türkçe ve Sosyal Bilgiler Eğitimi Bölümü, Kayseri, Türkiye; https://orcid.org/0000-0002-0861-0626

2. Erciyes Üniversitesi Eğitim Bilimleri Enstitüsü Yüksek Lisans Öğrencisi, Kayseri, Türkiye; https://orcid.org/0000-0001-8373-9959

Atıf / Citation: Öztürk, M., \& Gönülaçar, H. (2019).Öğretmenler Ne Zaman ve Nasıl Yetkin Bir Uzman Olurlar: Coğrafya Öğretmenleri Örneği. Kastamonu Education Journal, 27(2), 909-927. doi:10.24106/kefdergi.3115 


\section{Extended Summmary}

Introduction: Teachers start their professional careers in similar conditions, as novice teachers. And they go through a number of stages in their career cycles. The studies examining teachers' career cycles started to emerge in 1970s. One of early authors who studied teachers' career development is Unruh and Turner (1970). According to Unruh and Turner $(1970$, cited in Fessler, 1995) teachers go though three stages during their careers; the beginning of the profession, confidence building phase, and maturity phase. Another author who studied teachers' career development in 1970s was Gregorc (1970). Similar to Unruh and Turner, for Georg (1970 cited in Fessler, 1995), teachers complete three stages before becoming professional; starting stage, development stage, maturation stage and then professionalization (competent expert). Ryan (1979) also categorized teachers into four categories according to professional experi-ence: teachers working in their first years, teachers in the middle of their career (4 to 20 years), experienced teachers (20 to 30 years), and finally retired teachers (Fessler, 1995: 174). Studies on career development of teachers continued to attract attention by research-ers in later years. One of the most important studies in this context was Huberman (1995), with his work with Swiss secondary school teachers. Huberman grouped teachers' career paths under five headings as shown in Figure 1:

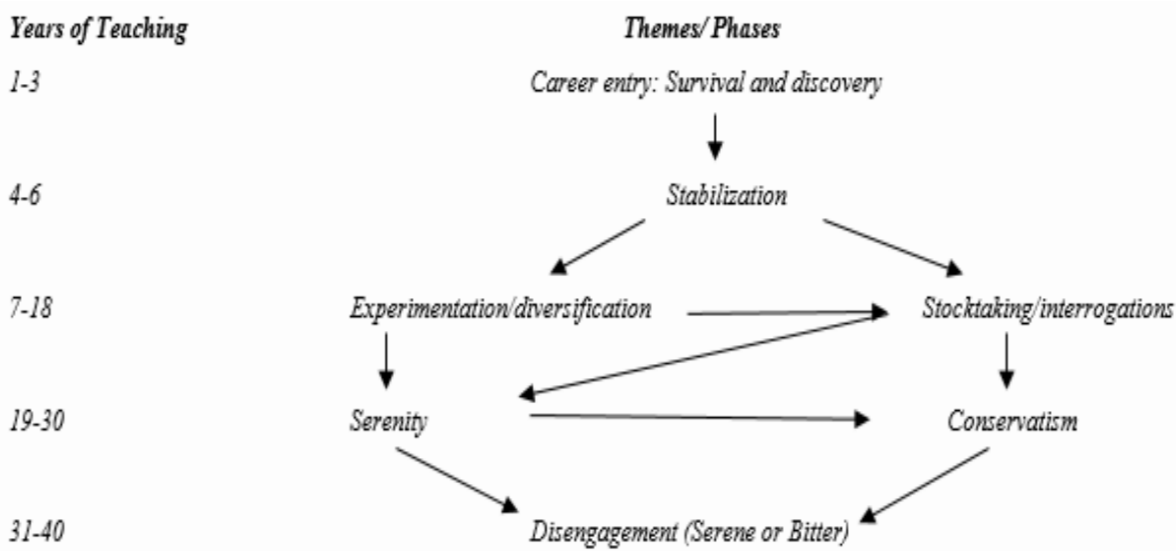

Figure 1. Teachers' career cycle (Huberman, 1995: 204)

However, not every teacher attains the level of competent expertise in their professional lives. In this study, teachers' process of being competent professionals; their career developments and how they learn the profession during their careers are examined in the case of geography teachers in Turkey.

Method : 25 geography teachers working in different school types across Turkey participated in the study. A purposeful sampling was ad-ministrated so that only teachers with more than 15 years of teaching experience were included in the study. The reason for this was concerned with the aims of the study that the authors wanted to evaluate the career development of teachers examining transitions to different stages. The data was collected through semi-structured interviews from May to July in 2018. The interviews lasted for 40-50 minutes. In order to ensure the confidentiality of the data, the participants of the study were randomly coded from KO1 to KO25. Audio recordings of the interviews were taken with the permission of the participating teachers, then the records were transcribed in Microsoft Word. Data analysed by content analysis method using QDA Miner Lite 2.0.5 qualitative analysis program. In the process, the data was first coded independently from the questions asked to the participants. Afterwards, the related codes were put together to create themes (Miles \& Huberman, 1994). As suggested by Miles and Huberman (1994), the analysis was not carried out at once and was performed concurrently with the data collection process. Such practice helped the researchers to develop additional questions and probes in the subsequent interviews. In order to provide consensus in the coding, the first seven interviews were analysed separately by two researchers. Although in the analysis of the first interview, the compliance rate of the codes carried out by the two researchers was around 40 percent and this rate increased to 90 percent in the fifth, sixth and seventh interviews. The remaining interviews were car-ried out by one of the researchers and then the two researchers checked the relevance of the codes one by one.

Findings: Three main themes were obtained from the content analysis. These are "first years of teaching", "career stages" and "professional development" (what kind of progress has been made in teaching professional skills). The participants generally learned about their profession from their role models (i.e. teachers from their own school years) and through their own experiences. Furthermore, the participants' motivations for professional development are usually low and it is generally not supported by different stakeholders. It appeared that the participants have usually not met the criteria required for the level of competent professionalism. However, they seemed to have had completed three career stages: Novitiate, transition to expertise, expertise.

The stage of novitiate; was considered to be between the first three and five years. This is the period during which participant teachers imitate their role models (i.e. another teacher / teachers). What characterizes this stage is a process of hard work in terms of improving their subject matter knowledge (i.e. geography knowledge). According to the participants' accounts, they did not have enough support from different stakeholders to have an easy beginning.

Transition to expertise; was the stage between the 6th and 14th years of the profession. This stage was characterised by increase in self-confidence and developing a routine. The teachers also appear to be distracted from the profession as they start to develop a family life. In particular, career development of female teachers seems to be interrupted 
as family responsibilities increase.

Expertise stage; was generally considered from the 15th and 16th years of the profession, the participant teachers stated that they have reached the level of expertise, in other words they are fully professionalized. The main reason why participants qualify themselves as an expert is related to sense of competency that they do thing without making an effort and they do not need any support or guidelines to carry out their profession. For some of the participants, this stage could also be described as a period of routine and tranquillity, while for some it was seen as a period of lack of motivation and energy.

Discussion and conclusion: Although the participants of the study passed the stages of novitiate, transition to expertise and expertise, it was found that they have not usually met the criteria required for the level of competent professionalism, in other words they are not yet fully professionals. According to Day (1999), the [competent] expertise is an analytical intuitive stage in which teachers should be in a constant search to make their work better. Therefore, although competent expertise is related to the year of service in the profession, just working certain period of time does not automatically make teachers competent experts. While the participants in the study have more than fifteen years of professional experience, few of them seem making significant efforts to improve themselves. It is also seen that generally professional development efforts by the Ministry of National Education are not designed with long-term goals based on a broad vision. What this study suggests then, there is a need for professional development initiatives to bring the teachers up to level of competent expertise. The key to greater achievements in professional development is related to the ability to question and develop knowledge through the use of reflective thinking rather than the discovery of new knowledge (Guskey, 1995). "This capacity is found in teachers who are constantly looking for better ways to observe different learning needs of students and are in continuous professional development" (Guskey, 1995, s. 126). 


\section{Giriş}

Türkiye'de öğretmenlik mesleğini seçmenin ve mesleğe kabul edilmenin kendine özgü şartları bulunmaktadır. Eğitim fakültelerinde okuyan öğrenciler ile farklı fakültelerde öğrenim görüp pedagojik formasyon eğitimi almak amacıyla eğitim fakültelerindeki programlara kaydolan öğretmen adaylarına "niçin bu mesleği seçtikleri" sorulduğunda, verilen cevaplar çoğunlukla merkezî sınavda istenilen alanda okumayı sağlayacak bir puanın alınamaması, ailenin yönlendirmesi, ilk veya orta öğretimde sevilen bir öğretmenin etkisi, istihdam edilme intimalinin yüksekliği ve özellikle bayanlar için günlük çalışma süresinin azlığı ile tatil döneminin uzunluğu gibi sebeplerin sayıldığı gözlenmektedir (Gümüş ve Çapar, 2011; Özder, 2014).

Öte yandan çoktan seçmeli sorularla yapılan sınavlar sonucunda, bir insan yetiştirme uzmanlığı olan öğretmenliği tercih edenlerin, bu seçimlerinin onların kişiliklerine, anlayışlarına, psiko-sosyal yapılarına ne derece uygun olduğu genellikle yeterince araştrılmamaktadır (Bu kapsamda gerçekleştirilmiş bazı çalışmalar için bkz., Karademir, 2012; Özder, 2014). Böylelikle, çoğunlukla tesadüflerin ya da gençlik hayallerinin etkisiyle öğretmenlik mesleğine aday olan gençlerin, daha başlangıçta profesyonel anlayışa uygun biçimde başvuru - eleme - kabul süreçlerini yaşamadıkları görülmektedir. Bu durumun bilhassa meslekî kariyer aşamaları ile mesleki gelişim sürecinde oldukça etkili sonuçlar doğuracağı muhakkaktır.

Bu çalışmada coğrafya öğretmenleri örneğinden hareketle, Türkiye'de öğretmenlerin yetkin uzman (tam anlamıyla profesyonel) olma süreci ile buna bağlı olarak ilerleyen kariyer gelişim aşamaları ile mesleklerini öğrenme süreçleri irdelenmiştir. Özellikle de araştırmaya katılan coğrafya öğretmenlerinin kariyerlerinin hangi aşamasında kendilerini acemi olarak nitelendirdikleri ve ne zaman yetkin uzmanlığa geçiş yaptkklarına ve bu bağlamda yeniliğe açık olma, kendini geliştirme, değişen şartlara uygun biçimde öğretmeyi öğrenme anlayışlarının ne olduğuna odaklanılmıştır.

\section{Öğretmenlerin kariyer gelişim aşamaları}

Öğretmenler, meslek hayatlarının herhangi bir döneminde bir kariyer basamağında yer almaktadırlar ve tecrübeleri onların kariyerlerine yön vermektedir (Day, 1999). Öğretmenlerin kariyer aşamaları üzerine ilk çalışmalar 1970'li yıllarda ortaya çıkmaya başlamıştır. Bu aşamaları ilk defa belirleyenler arasında yer alan Unruh ve Turner'a (1970, akt. Fessler, 1995, s. 173) göre öğretmenler şu üç kariyer aşamasından geçerler:

1) Mesleğe başlangıç aşaması: Yaklaşık ilk 5 yılı kapsayan bu dönemde, öğretmenler; okul yönetimi, günlük planlar, öğretim programını benimseme ve personelin geri kalanı tarafindan kabullenilme sorunları ile baş etmeyi öğrenirler.

2) Güven inşa etme aşaması: Bu dönem, 6. ile 15. yıllar arasını kapsar. Bu dönemdeki öğretmenler, kariyerlerinin en mutlu dönemlerini yaşarlar. Çünkü "ne yaptkklarını bilirler". Kendilerini akademik anlamda geliştirmek için yollar ararlar. Hem maaşlarını artırmak hem de kariyerlerini geliştirmek için ek kurslarla yeni beceriler kazanmaya çalışırlar.

3) Olgunluk aşaması: 15 yıllık mesleki tecrübeden itibaren başlayan bu dönemde, öğretmenler mesleki hayatlarının en dingin dönemine geçiş yaparlar. Siyaset, sanat, müzik gibi okul dışı başka aktivitelere meylederler.

Öğretmenlerin kariyer aşamalarını çalışan ilk dönem yazarlardan Gregorc (1970, akt. Fessler, 1995) ise, öğretmenlerin, geçtikleri üç aşamadan sonra profesyonelleştiklerini belirtir. Bunlar; başlangıç aşaması, gelişme aşaması, olgunlaşma aşaması ve sonrasında profesyonelleşmedir (yetkin uzman olma). Ryan (1979) da öğretmenleri mesleki tecrübelerine göre dört kategoride sınıflandırmıştır: İlk yıllarını çalışan öğretmenler, kariyerinin ortasında olan öğretmenler (4 ile 20 yıl arası), tecrübeli öğretmenler (20 ile 30 yıl arası) ve son olarak emekli öğretmenler (Fessler, 1995).

Öğretmenlerin kariyer gelişimlerine yönelik çalışmalar, sonraki yıllarda da, araştırmacılar tarafından ilgi görmeye devam etmiştir. Bu kapsamdaki önemli çalışmalardan birine Huberman (1995), İsviçreli ortaöğretim öğretmenleriyle yaptığı çalışması ile imza atmıştır. Huberman, çalışmaları sonucu oluşturduğu kariyer dönemlerini Şekil 1'de gösterildiği gibi beş başlık altında toplamıştır:

Huberman (1995)'nın kariyer gelişimi modelinde, öğretmenlerin mesleğe genellikle iki şekilde başladıkları belirtilmektedir: Başlangıç ya sıkıntılı ve zor ya da eğlenceli ve kolay olabilir. Başlangıç sürecinin kolay ya da zor olmasını etkileyen temel faktörler, öğretmenlerin sadece kişilikleriyle ilgili değildir. Öğretmenin sınıf yönetimi ve problem çözme becerisi, öğretim programı ve pedagojik konularla ilgili bilgisi, okul kültürüne uyum ve iş arkadaşlarının desteği de sürecin nasıl şekilleneceği üzerinde etkilidir. Bu dönem mesleğin ilk birkaç yılı boyunca sürmektedir. 
Hizmet süresi (y11)

$1-3$
Evreler

Kariyerin başlangıc1: Keşfetme ve hayatta kalma

(kolay ya da zor başlangıçlar)

Stabilizasyon, istikrar

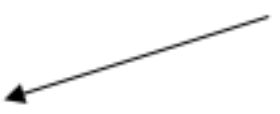

Deneyimsel uyarlamalar yapma ve çeşitlendirme
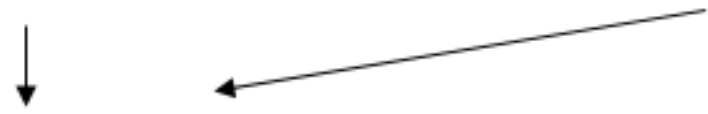

Huzur ve dinginlik
Mesleği sorgulama

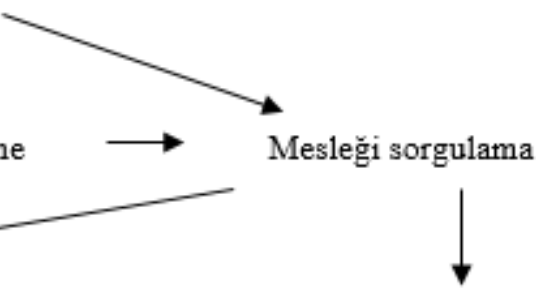

Tutuculuk

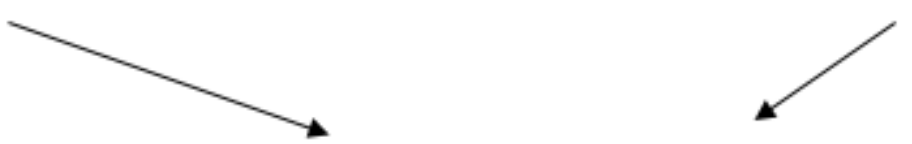

Mesleki ilgilerin ve kaygiların iyice azalmas1, geri çekilme (ya dingin ya da huzursuz şekilde)

\section{Şekil 1. Öğretmenlerin kariyer çevrimi (Huberman, 1995, s. 204)}

Öğretmenlerin meslek yaşantılarının yaklaşık 4. ile 6. yılları arasındaki dönemi Huberman (1995) istikrarlı dönem olarak adlandırmaktadır. Bu dönemde hem iş arkadaşları hem de okulun diğer personeli, öğretmenin tecrübe kazandığını kabul ederler. Olgunlaşma hissinin profesyonelleşmeye doğru evrildiği bu dönemde, okul ve okul dışı eğitim çalışmalarının daha geniş bir yelpazede gerçekleştirildiği gözlemlenebilir. Kariyer döngüsünün orta evrelerindeki öğretmenler (7-18 yıllık kıdem) artık profesyonel platoya ulaşmışlardır. Kendilerinden daha az ve daha çok kıdemli meslektaşlarından daha farklı ve çeşitli tutumlar sergilemeleri muhtemeldir. Bu çeşitlilik; kariyer ilerlemesi, okul kültürüne tam uyum ve karşılarına çıkacak her türlü paradoksal durumla nasıl baş ettikleri ile ilgili olacaktır. Ayrıca bu yıllar, orta yaş krizinin yaşanma ihtimali olan bir dönemdir ve öğretmenler, rollerindeki değişim ve beklediği terfii alamama gibi sebeplerle motivasyon kaybı yaşayabilirler.

Huberman (1995)'nın belirttiğine göre, sağlık veya ailevi kaygılarının artması potansiyeli de olsa, teorik olarak en önemli uzmanlık aşaması, mesleğin 20. yılı ile 40. yılı arasında gerçekleşir. Bu dönem öğretmenlerin en "tutucu" oldukları dönem de olabilir. Bu aşamadaki öğretmenler, "zamane" öğrencilerinin ve öğretmenlerinin davranışları, değer ve tutumları hakkında daha fazla şikâyette bulunurlar. Değişimin gerekliliği ve erdemleri konusunda şüpheleri vardır. Yani öğretmen ile öğrencisi arasında belirgin bir kuşak çatışması yaşanır. Artık terfi almak gibi bir amaç peşinde koşmadıklarından, bu aşamadaki öğretmenler, ya boş vermiş ya da hissettikleri olumsuz duygularla huzursuz/mutsuz (bitter) bir şekilde mesleklerini sürdürürler. Huberman (1995)'a göre en ideal kariyer gelişimi Şekil 1'deki modelin sol tarafi boyunca gerçekleştirilendir: Keşfetme - deneyimsel uyarlamalar yapma ve sınıf içi etkinlikleri çeşitlendirme - huzurlu bir şekilde uzmanlığın tadını çıkarma - dingin bir şekilde mesleğe yönelik ilgi ve kaygılarını azaltarak emekli olma.

Başta öğretmenler olmak üzere tüm uzmanlık gerektiren mesleklerde yetkin bir uzmanlığı başarabilmek için gerekli becerilerin nasıl edinildiğini ortaya koyan çalışmaların en önemlilerinden birisi, Dreyfus Modeli'dir. Dreyfus'un Beceri Gelişimi Modeli'nin (Dreyfus Model of Skill Acquisition) temelini, bir meslekte başarılı olabilmek için acemilerin (novices) katı kural ve rehberlere ihtiyaç duymalarına karşın; katı kuralların, uzmanların verimliliğini düşüren, onların içgüdülerini ve uzmanlıklarını sınırlayan bir faktör olduğu fikri oluşturur (Dreyfus \& Dreyfus, 1980). Dreyfus ve Dreyfus'un (1980) modelinde uzmanlık gerektiren bir alanda gerekli becerilerin kazanılması beş aşamalı bir süreçtir: Acemilik, kalfalık, yetkinlik, ustalık ve uzmanlık dönemleri. Day (1999, s. 50), bu modeli öğretmenlere aşağıdaki şekilde uyarlamıştir; buna göre, öğretmenler bu beş aşama sonucunda mesleklerinde uzmanlaşırlar.

\section{Acemilik (çıraklık) dönemi (Novice):}

Bu dönemde mesleğe yeni başlamış öğretmenlerin;

- Takdir yetkisi gelişmemiştir, 
- Kurallara sıkı bir bağlılığı vardır,

- Durumsal olayları algılamaları sınırlıdır.

- Büyük resimle ilgilenmezler, kendilerine verilen görevi bitirmeye odaklanırlar.

Kalfalık (ileri acemilik) dönemi (Advanced beginner):

Bu dönemde öğretmenler;

- intiyaçları olan bilgiye çabucak erişmek isterler.

- Hâlâ büyük resimle ilgilenmemelerine karşın, içinde bulundukları bağlamı kavramaya başlarlar.

- Bazı deneyimlerden sonra ortaya çıkan durumlarda kendi görüş ve öz niteliklerine uygun eylemler geliştirirler.

- Durumsal olayları algılamaları hâlâ sınırlıdır. Bazı şeyler yanlış gittiğinde ne yapacaklarııı bilemeyebilirler.

- Tüm nitelikleri ve durumları ayrı ayrı ele alırlar ve bunlara eşit önem verirler.

\section{Yetkinlik dönemi (Competeny phase):}

Bu dönemde öğretmenler;

- Kalabalık sınıflarla ve öğrenci gruplarıyla baş edebilir hale gelirler.

- Arttk eylemlerini kısmen, uzun vadeli bir sürecin parçası olarak görürler.

- Bilinçli bir şekilde planlama yaparlar.

- Standart ve rutin uygulamalar geliştirirler.

- Ani gelişen durumlarla, tecrübelerini işe koşarak baş edebilirler.

- Uygulamaları hakkında yansıtıcı düşünme (reflection) becerileri hâlâ sınırlıdır.

Ustalık dönemi (Proficiency phase):

Bu dönemde öğretmenler;

- Olaylara bütüncül bir perspektiften bakar ve çok yönlü düşünürler. Büyük resmi görmeden verimli bir şekilde çalışmazlar.

- Ne kadar etkili oldukları hakkında yansıtıcı düşünme (reflection) gerçekleştirirler ve kendi gelişimleri için tecrübelerini işe koşarlar.

- Bir durumda neyin önemli neyin önemsiz olduğunu anlayabilirler.

- Normal gidişattan sapmaları anlarlar ve böyle bir durumda ne yapılması gerektiğine hızla karar verirler.

- Onlar için karar vermek daha az yorucudur.

- Olayları veya durumları yönetmek için talimatları kullanmalarına karşın duruma göre uyarlamalar yaparlar.

[Yetkin] Uzmanlık dönemi ([Competent] Expert):

Bu dönemde öğretmenler;

- Kurallara, rehberlere ya da talimatlara intiyaç duymazlar.

- Olayları, geliştirmiş oldukları derin algılama sayesinde sezgileriyle hemen anlayıp kavrarlar. Herhangi bir durumda ne yapmaları gerektiğini içgüdüsel olarak bilirler.

- Analitik yaklaşımı sadece özgün olaylar ve problemli durumlar karşısında sergilerler.

- Geleceğe dönük neyin mümkün olduğuna dair bir perspektif sahibidirler.

- Bir şeyleri daha iyi yapmak için daima arayış içindedirler.

Gerek Unruh \& Turner (1970) ve Huberman (1995)'a göre gerekse de Day (1999)'e göre, öğretmenler mesleki yaşantılarına benzer şartlarda/özelliklerle acemi (novice) bir şekilde başlarlar. Ancak yetkin bir uzmanlığa ulaşmak her öğretmen için mümkün olmayabilir. Hemen her öğretmen, hizmet süreleri itibariyle acemilik, kalfalık, yetkinlik ve ustalık dönemlerinden geçseler de ancak bazıları yetkin bir uzman ve dolayısıyla bir profesyonel olarak nitelenebilmektedir.

\section{Yöntem}

\section{Çalışma grubu}

Bu çalışma, Türkiye'nin farklı illerinde ve farklı lise türlerinde görev yapan, hizmet süresi on beş yıl ve üzeri olan toplam 25 coğrafya öğretmeninin katılımıyla gerçekleştirilmiştir. Hizmet süresinin 15 yılı aşkın olması araştırmacılar tarafından özellikle tercih edilmiştir. Bunun temel sebebi, öğretmenlik mesleğinde artık oldukça uzmanlaşmış, meslekî doyuma ulaşmış oldukları varsayılan bu öğretmenlerin hangi kariyer aşamalarından geçtiklerinin araştrılmasının yanı 
sıra, öğretmenlik gibi öğrenmenin sürekli olduğu bir meslekte öğrenmeyi nasıl devam ettirdiklerinin sorgulanması imkânına daha fazla sahip olmaktır. Bu öğretmenlerin 18'i erkek, yedisi kadındır. Kadın öğretmen sayısının azlığının sebebi, araştırmacıların girişimlerine rağmen bazı kadın öğretmenlerin görüşme yapmak istememelerinden kaynaklanmıştır. Araştrrmaya katılan öğretmenlerin hizmet süreleri Tablo 1'de gösterilmiştir.

Tablo 1. Kathlımcıların meslekteki çalışma süreleri

\begin{tabular}{cc}
\hline Meslekteki hizmet süresi (yıl) & Katlımcı sayısı \\
\hline 15 & 2 \\
$16-20$ & 7 \\
$21-25$ & 9 \\
$26-30$ & 5 \\
$31-35$ & 2 \\
\hline Toplam & 25 \\
\hline
\end{tabular}

\section{Veri toplama aracı}

Bu nitel çalışmada yarı yapılandırılmış görüşme tekniği kullanılmıştır. Yarı yapılandırılmış görüşme, araştırmacıyı rahatsız eden veya meraklandıran herhangi bir konuda belirlediği açık uçlu sorularla veri toplama stratejisidir (Yıldırım ve Şimşek, 2016). Yarı yapılandırılmış görüşme kullanan araştırmacılar, görüşmeden önce katılımcılara sormak üzere soru hazırlamak yerine konu başlıkları belirleyerek daha ziyade görüşmeyi sohbet havasında sürdürmeyi amaçlar (Öztürk, 2014). Bu başlıklar, dikkatli bir şekilde seçilmiş konuların bir listesi olabilir. Araştırmacı, bu başlıkları görüşmenin gidişatna göre farklı şekillerde ve sıralamada sohbetin içine dağıtarak katılımcılara sorar. Anlaşılamayan durumlarda konuyu biraz daha açık hale getirebilir. Yarı yapılandırımış görüşmeler genelde araştırmacıyla katılımcılar arasında samimi bir diyalog oluşmasını sağlarken, katılımcılar kendilerini sınanıyor gibi hissetmedikleri için daha içten cevaplar vermektedirler. Ayrıca katılımcılar için her soruya sabit ve eşit cevap aralığı olmadığı için işin içine duygular da katılır. Araştırmacıların bir görevi de katılımcılardaki bu duygusal ifadeleri not etmektir (Ayress, 2008). Bu da bulguların daha gerçekçi oluşmasına büyük katkı sağlamaktadır. Yarı yapılandırılmış görüşmeler, aralarındaki kavramların ve ilişkilerin nispeten iyi anlaşıldığı araştırma soruları için özellikle yararlıdır (Ayress, 2008).

\section{Veri toplama süreci ve analizi}

Çalışma grubunu oluşturan coğrafya öğretmenleri ile yapılan görüşmeler, 2018 yılı Mayıs-Temmuz döneminde gerçekleştirilmiştir. Görüşmeler 40-50 dakika aralığında sürmüştür. Verilerin gizliliğinin sağlanarak çalışmanın güvenirliğini artırmak için çalışmaya katılan coğrafya öğretmenleri Katılımcı Öğretmen (KÖ) 1'den den KÖ25'e kadar rastgele kodlanmıştır. Kathlımcı öğretmenlerin izniyle görüşmelerin ses kaydı alınmış, daha sonra kayıtlar araştırmacılar tarafindan Word ortamına aktarılmış ve QDA Miner Lite 2.0.5 nitel analiz programıyla içerik analizine tabi tutulmuştur. Buna göre, öncelikle elde edilen görüşme dökümleri katılımcılara sorulan sorulardan bağımsız olarak kodlanmıştır. Illişkili kodlar bir araya getirilerek temalar oluşturulmuştur (Miles \& Huberman, 1994). Miles ve Huberman (1994)'nın önerdiği şekilde analiz tek seferde gerçekleştirilmemiş olup veri toplama süreci ile eş zamanlı gerçekleştirilmiştir. Bu sayede ilk yapılan görüşmelerden elde edilen temel bulgular neticesinde sonraki görüşmelerde katlımcılara ek sorular ve sondalar yöneltilmiştir. Kodlamada görüş birliği sağlayabilmek için ilk yedi görüşme dökümleri iki araştırmacı tarafindan ayrı ayrı gerçekleştirilmiş ve karşılaştıııması yapılmıştı. Illk görüşmenin analizinde iki araştrmacı tarafindan gerçekleştirilen kodların uyum oranı yüzde $40^{\prime} l a r$ civarında iken beşinci, altıncı ve yedinci görüşme dökümlerinde bu oran yüzde $90^{\prime} l a r a$ çıkmıştr. Geri kalan görüşmeler araştırmacılardan birisi tarafindan gerçekleştirilmiş ve sonrasında iki araştırmacı tarafindan tüm görüşmelerdeki kodların uyumu teker teker kontrol edilmiştir. Miles ve Huberman (1994) tarafindan önerilen güvenirlik formülü esas alındığında, kodlama sürecinde iki yazar tarafindan gerçekleştirilen kodlamalar arasındaki uyuşum oranı yaklaşık $\mathrm{P}=92$ bulunmuştur. Miles ve Huberman’nın güvenirlik formülü şu şekildedir: Örtüşme yüzdesi $(\mathrm{P})=$ Fikir birliği $(\mathrm{Na})$ / (Fikir birliği (Na) + fikir ayrılı̆̆ (Nd)) x 100. Elde edilen bu değere göre, gerçekleştirilen kodlamanın yüksek derecede kabul edilebilir olduğu düşünülmüştür.

\section{Bulgular}

Gerçekleştirilen içerik analizi sonrasında üç ana temaya ulaşılmıştır. Bunlar, "öğretmenlikte ilk yıllar", "kariyer dönemleri" ve "mesleki gelişimler" (meslekte öğretmenlik becerisiyle ilgili nasıl bir gelişim gösterdikleri)'dir. Bu temalar 
altında elde edilen bulgular aşağıda sunulmuştur.

\section{Öğretmenlikte ilk yıllar}

Daha önce literatür taraması bölümünde belirtildiği gibi öğretmenlerin profesyonellik algıları ve uygulamalarını etkileyen önemli faktörlerden birisi mesleğin ilk yıllarıdır. Bu düşünceden hareketle görüşme sırasında katılımcı öğretmenlere mesleklerinin ilk yıllarının nasıl geçtiği (tatmin edici mi yoksa zorlayıcı mı olduğu) hakkında değerlendirme yapmaları istenmiştir.

Katılımcılardan mesleğe başladıkları ilk yıllarla ilgili yaptıkları değerlendirmeler Tablo 2'de beş madde hâlinde özetlenmiştir. Katılımcıların yarısından fazlası ( $f=15)$, mesleğin ilk yıllarını acemilik dönemi olarak nitelendirmişler ve genel anlamda bu dönemin bilgi açısından eksikliğini hissettikleri konulara yönelik olarak ders çalışarak geçirdikleri bir dönem olduğunu belirtmişlerdir.

\section{Tablo 2. Öğretmenliğin ilk yılları}

\begin{tabular}{lc}
\hline \multicolumn{1}{c}{ Katılımcı görüşleri } & Frekans \\
\hline Acemilik ve eksiklerimi tamamlamakla geçti & 15 \\
İdealistlikle ve çok çalışmakla geçti & 7 \\
Üniversite son sınıfta ya da mezun olunca dershanede çalışmakla geçti & 4 \\
Doğuda can güvenliği tehlikesiyle geçti & 3 \\
Evlilik ve çocuk sahibi olmakla geçti & 1 \\
\hline Toplam & 30 \\
\hline
\end{tabular}

Tablo 2'de en çok dile getirilen "acemilik ve eksiklerimi tamamlamakla geçti ( $f=15$ )" ile "idealistlikle ve çok çalışmakla geçti $(\mathrm{f}=7)$ " maddeleri farklı öğretmenler tarafindan dile getirilmiştir. Esasen mesleğinin ilk yıllarını idealist bir anlayışla çok çalışarak geçirdiği ifade eden yedi öğretmen de, acemi olduklarını kabul etmektedirler. Ancak onların ilk yıllarını acemilikle geçirdiğini belirten katılımcılardan farklı bir motivasyonla çalışmalarını yürüttükleri görülmektedir. illk grup öğretmenlerin daha çok "hayatta kalma" kaygısıyla özellikle sınıf yönetimi ve disiplin gibi konulara ağırlık verdikleri görülmektedir:

“Öğretmenliğin ilk yılı tamamen tecrübesizlikle geçti diyebilirim, üniversiteden yeni çıkmıs oluyorsunuz. Genel sınıf yönetimi noktasında eksikleriniz çok. Tabii burada Eğitim Fakültesinden mezun olmanın da faydası var ancak ne kadar üniversitede formasyon dersleri alsak ve son sınıfta staj uygulaması yapsak da acemilik oluyor." (KÖ10, Mülakat dökümü).

İkinci grup öğretmenler ise sınıf yönetimi ya da "hayatta kalmak" gibi endişelerin ötesinde bizatihi öğrencilerin öğrenmelerini sağlamaya yönelik çaba göstermişler, kendilerini farklı yöntemler denerken ya da çeşitli materyaller geliştirirken bulmuşlardır:

“....Mesleğimin ilk yılında gece sabahlara kadar çalıştı̆ımı bilirim. O dönemde bilgisayarlar yaygın olmadığından, materyallerimi kendi ellerimle hazırlardım. Renkli kâğıtlara çizimler yapar, grafikler ve tablolar oluştururdum. Öğrencilerin daha iyi nasıl anlayacaklarını düşünüp ona göre ders planları hazırlardım." (KÖ25, Mülakat dökümü)

Üçüncü olarak ise sosyo-ekonomik ve ailevi şartların da meslek başlangıcında öğretmenlerin performanslarını etkilediği görülmektedir. Bu çalışmaya katılan öğretmenlerden dördü ekonomik sebeplerle mesleğe dershane ortamında başladıklarını belirtmişler ve bu onların öğretmenlik uygulamalarını etkileyen bir faktör olmuştur:

"Mesleğimin ilk yılı dershanede çalışarak geçti. Oradaki kıdemli bir meslektaşımdan aldığım yönlendirmeler meslek hayatımda önemli bir fark oluşturdu. Meslektaşımın bana soru bankalarındaki soruları analiz etmem gerektiğini önermişti. Yine ilk yılımda coğrafya derslerinin ne kadar görselleştirilirse o kadar verimli olacağını anladım. Meslek hayatım boyunca da daima derslerimi görselleştirerek, haritalar çizerek, animasyon hazırlayarak geçirdim." (KÖ21, Mülakat dökümü)

Katılımcıların iş performanslarını doğrudan etkileyen diğer bir faktörün ise sosyal ve fiziksel çevre koşulları olduğu görülmektedir. Bu kapsamda bazı katıımcılar, çalıştıkları bölgenin güvenli olmayışı ile ilgili duydukları kaygıyı $(f=3)$ ve çocuk sahibi olmanın getirdiği sorumlulukları ön plana çıkarmıştır $(f=1)$. 
“Mesleğimin ilk yılında, Doğu'da terörün kol gezdiği ortamda, sınıftaki öğrencilerin size karşı düşmanca tavırlar takındığı bir ortamda çalıştım. Bir yıl boyunca okulun kapalı olduğu dönem bile oldu. Bu süreçlerde yardım alabileceğim herhangi bir zümrem de yoktu. Esasen şimdi bulunduğum yere gelinceye kadarki dönemimi bu sebepten acemilik dönemi olarak görüyorum." (KÖ14, Mülakat dökümü)

"Öğretmenliğimin ilk yılında bir çocuğum daha oldu. Dolayısıyla benim için öğretmenliğimin ilk üç yılı ve hatta beşinci yılıma kadar hep çocukları büyütmekle geçti. Tabi, bu arada öğretmenliğimin ilk beş yılında derslere gire çıka bir şeyleri öğrenmeye başlamıştım." (KÖ11, Mülakat dökümü)

KÖ11'in de ifade ettiği gibi bazı kadın öğretmenler için meslek hayatlarının ilk yılları evliliklerinin ilk yıllarıyla çakıştığı için mesleki gelişimlerine, bir katıımcının belirttiği gibi, ya "erken havlu atmaktalar" ya da bu yola geç başlamaktadırlar.

\section{Mesleki kariyer dönemleri}

Araştırmaya katılan öğretmenler, yukarıda görüldüğü gibi mesleğe başladıkları ilk yılları genellikle acemilik dönemi olarak nitelendirmişlerdir. Ancak acemiliğin kaç yıl sürdügü üzerinde katılımcılar hem fikir değildirler (Tablo 2).

Tablo 3. Öğretmenlikte acemilik dönemi

\begin{tabular}{lc}
\hline \multicolumn{1}{c}{ Katılımcı görüşleri } & Frekans \\
\hline ilk üç yılını acemilik dönemi olarak niteleyenler & 11 \\
illk beş yılını acemilik dönemi olarak niteleyenler & 6 \\
ilk yedi-sekiz yılını acemilik dönemi olarak niteleyenler & 4 \\
illk dört yılını acemilik olarak niteleyenler & 3 \\
Illk on yılını acemilik olarak niteleyenler & 1 \\
\hline Toplam & 25 \\
\hline
\end{tabular}

Tablo 3'deki bulguların yığılmalı grafik olarak gösterimi Şekil 2'de gösterilmiştir. Şekil 2'de görüldüğü gibi öğretmenlerin yarıdan fazlası $(f=14)$ meslekteki ilk üç ve dört yılını acemilik dönemi olarak nitelendirmişlerdir. Bu grup öğretmenlerin aşağıdaki örnek alıntılardan da rahatlıkla görülebileceği gibi genel olarak mesleğin ilk üç / dört yılını acemilik olarak nitelendirmelerinin temel sebebi, bu süre içerisinde lisedeki tüm sınıf düzeylerinde derse girerek konulara hâkim olmalarıdır:

"Benim için ilk üç yıl acemilik dönemiydi diyebilirim. Çünkü o zamanlar lise üç yıldı ve bu süre içinde tüm sınıf seviyelerinde derslere gire gire arttk konulara hâkim olmaya başlamıştım." (KÖ11, Mülakat dökümü)

"ilk dört yıl acemilik yaşadığımı düşünüyorum. Muş’taki yıllarımda. Oradaki yıllarım şöyle geçti. İlk yılım stajyerlikle ve stajyer dosyamı kendi elimle sayfa sayfa yazmakla, diğer üç yıl da sürekli derslere çalışmakla geçti. O yıl liseler üç yıldı bilirsiniz belki." (KÖ1, Mülakat dökümü)

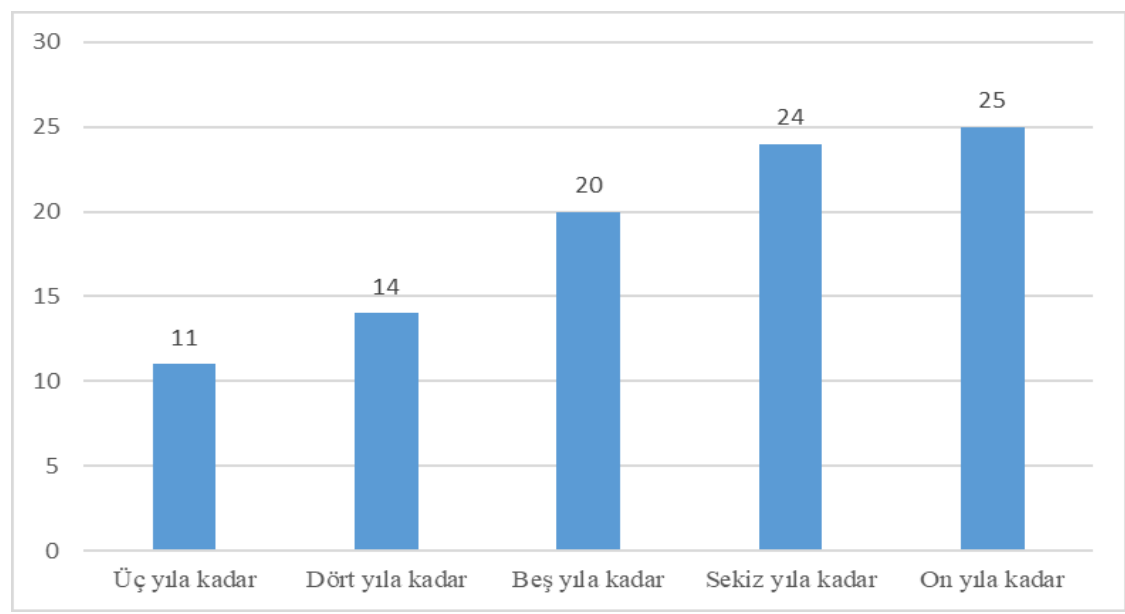

\section{Şekil 2. Öğretmenlikte acemilik dönemi yığılmalı grafik}

Toplamda altı katılımcı, meslekteki ilk beş yılının acemilik dönemi olduğunu belirtmiştir. Esasen ilk beş yılını acemilik 
dönemi olarak niteleyen öğretmenler de genellikle bu süreçte konulara hâkim olmak için çok çalıştiklarına vurgu yapmışlardır:

“Öğretmenliğimin ilk beş yılını acemilik olarak nitelendirilebilirim. Çünkü bu dönemde tayinim Şebinkarahisar ilçesine daha yeni çıkmışt ve orada tek öğretmendim. Tek zümre çalıştım ve bana danışmanlık edecek herhangi bir hoca desteği göremedim. Otuz saat art alt saatte başka bir okulda toplam otuz alt saat derse giriyordum, teknolojiden uzak bir yerde sabahlara kadar çok çalışırdım." (KÖ25, Mülakat dökümü)

Şekil 2'den görülebileceği gibi katılımcıların büyük çoğunluğu (toplamda 20 katılımcı) acemiliklerini mesleklerinin ilk beş yıllık süreci içerisinde attklarını düşünmektedirler (üç, dört ve beş yılını acemilik dönemli olarak nitelendirenler). Bu dönemi acemilik olarak nitelendirmelerinin temelinde ise genellikle tüm sınıf düzeylerinde (lise 1, 2 ve 3 olmak üzere) derse girme firsatını bu süreçte yakalamaları ve farkıı sınıf düzeylerindeki konulara hâkim olabilmek için çok çalışmaları yatmaktadır.

İlk yedi veya sekiz yılını acemilik dönemi olarak niteleyen öğretmenlerin de genellikle temel argümanı coğrafya alan bilgisine dair yeterliklerinin gelişmesiyle ilgidir. Çünkü bu grup öğretmenler mesleğe ya sosyal bilgiler öğretmeni ya da sınıf öğretmeni olarak başlamışlar ve daha sonra coğrafya öğretmeni olarak lisedeki ilk yıllarında alan bilgisi açısından acemilik çekmişlerdir:

"ilk yedi yılım acemilik döneminde geçti diyebilirim. Bunun ilk dört yılı sosyal bilgiler öğretmeni olarak çalıştğıım yıllar. Daha sonra branşıma geçince o dönemde de branşımla ilgili dört yıllık konulara uzak kalmanın verdiği bir acemilik vardı." (KÖ18, Mülakat dökümü)

“Kayseri'ye gelene kadar aşağı yukarı sekiz yıl çalıştım. illk görev yerim Diyarbakır'dı. Diyarbakır'da sosyal bilgilerde çalışmıştım. Diyarbakır o yıllarda karışık dönemlerdi, neredeyse bir yıl boyunca okullar hiç açılmadı, okula gittiğimiz gün sayılıdır... O dönemlerimi öğretmenlikten saymıyorum”. (KÖ14, Mülakat dökümü)

Öğretmenliğinin ilk on yılını acemilik olarak niteleyen tek bir katılımcı ise, aşağıdaki sözlerinden de anlaşılacağı gibi, esasen mütevazı bir tutum sergilemektedir. Çünkü öğretmenlerin meslek hayatlarının hemen her döneminde yeni ve farklı grup öğrencilerle muhatap olmalarının, daima yeni şeyler öğrenmelerine yol açtığını düşünmektedir:

"Ben hep kendimi acemi olarak görüyorum. Çünkü her yıl çok değişik öğrencilerle karşılaşt̆ğım için kendimi yetiştirme adına hep acemi olarak düşünüyorum." (KÖ16, Mülakat dökümü)

Görüşme sırasında katılımcılara şu an itibariyle kendilerini yetkin bir uzman olarak görüp görmedikleri ve mesleki kariyerlerinin hangi yılından itibaren kendilerini yetkin bir uzman olarak görmeye başladıklarını belirtmeleri istenmiştir. Araşttrmaya katllan öğretmenlerin tamamı, görüşmenin yapıldığı an itibariyle, kendilerini yetkin bir uzman öğretmen olarak nitelendirdiklerini belirtmişlerdir. Tablo 4, katılımcıların kendilerini ne zaman uzman olarak görmeye başladıklarına dair değerlendirmelerini özetlerken, Şekil 3 bu bulguları yı̆ı̆ımalı grafik halinde göstermektedir.

\section{Tablo 4. Öğretmenlikte uzmanlık dönemi}

\begin{tabular}{lc}
\hline \multicolumn{1}{c}{ Katılımcı görüşleri } & Frekans \\
\hline 15. yıldan itibaren uzmanlık dönemim diyenler & 7 \\
16. yıldan itibaren uzmanlık dönemim diyenler & 6 \\
10. yıldan itibaren uzmanlık dönemim diyenler & 4 \\
18. yıldan itibaren uzmanlık dönemim diyenler & 3 \\
13. yıldan itibaren uzmanlık dönemim diyenler & 2 \\
9. yıldan itibaren uzmanlık dönemim diyenler & 1 \\
11. yıldan itibaren uzmanlık dönemim diyenler & 1 \\
12. yıldan itibaren uzmanlık dönemim diyenler & 1 \\
\hline Toplam & 25 \\
\hline
\end{tabular}

Tablo 4'de görüldüğü gibi katlımcıların kendilerini yetkin bir uzman öğretmen olarak görmeye başladıkları dönem acemiliğe (Tablo 3) göre daha çeşitlidir. Elde edilen bulgular kendi içinde sınıflandırıldığında Tablo 5'deki ve Şekil 3'deki gibi bir sonuca ulaşılabilir. 
Tablo 5. Yetkin uzmanlığa geçiş dönemi

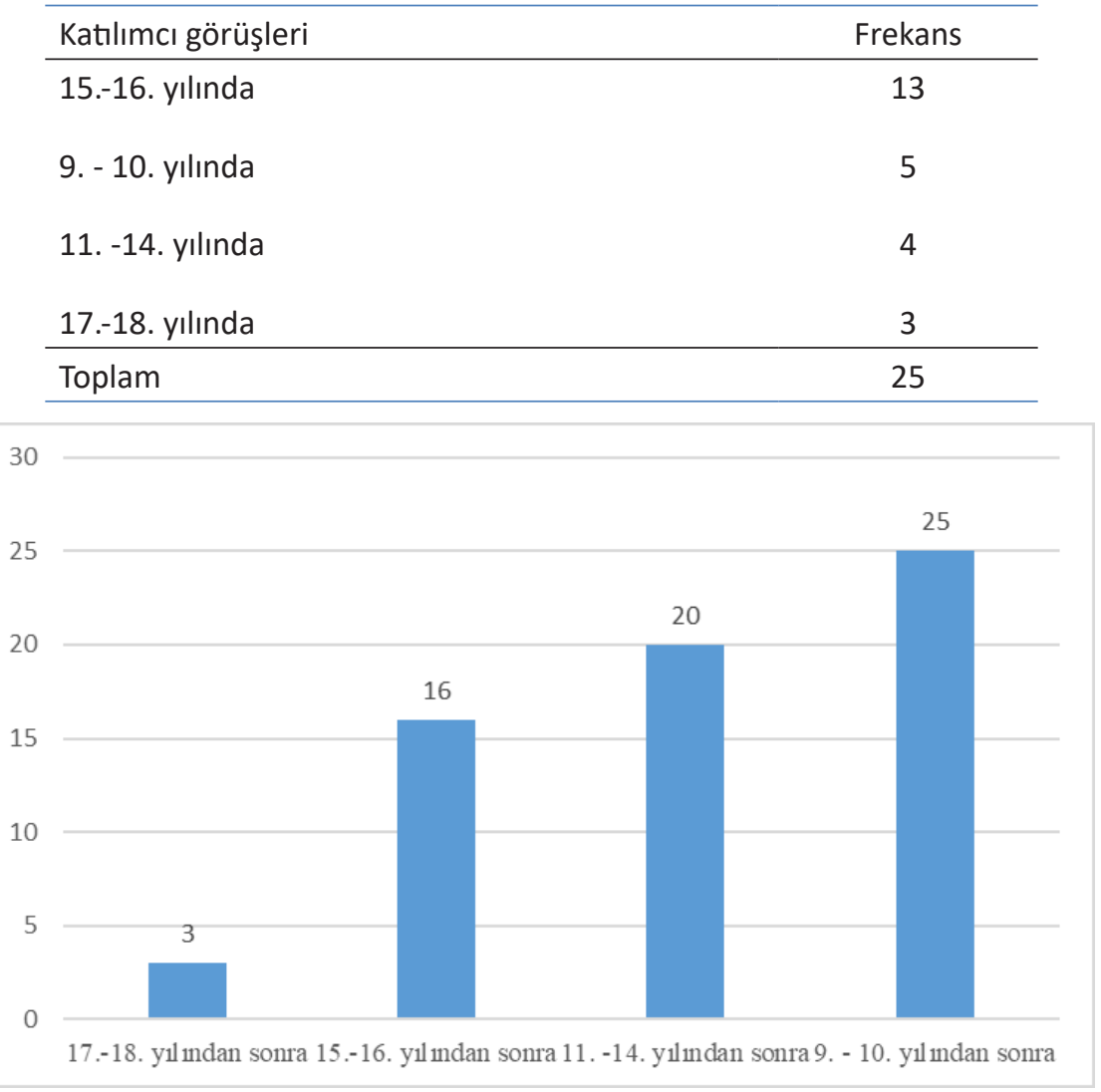

\section{Şekil 3. Yetkin uzmanlığa geçiş dönemi yığılmalı grafiği}

Şekil 3'den hareketle çalışmaya katılan tüm öğretmenler açısından değerlendirildiğinde meslekte 9.-10. yıldan önce uzman olmak mümkün değildir. Ancak yine Şekil 3'de görüldüğü gibi sadece üç katılımcı 17.-18. yıllarından itibaren uzman olunabileceğini belirtirken, beş katılımcı 9.-10. yıllardan itibaren uzmanlaştılarını dile getirmişlerdir. Esasen katılımcıların uzmanlık dönemleriyle ilgili değerlendirmeleri ile hâlihazırdaki mesleki deneyimleri arasında bir ilişkinin varlığı söz konusudur. Çünkü yirmi yıl ve üstü mesleki tecrübeye sahip olan katılımcılar, genellikle meslekteki 15. ve 16. yıllarından itibaren kendilerini uzman olarak görmeye başladıklarını belirtmişledir. Bu bağlamda sekizi 20 yıl ve üzeri mesleki deneyime sahip katılımcılardan oluşmak üzere toplamda on üç öğretmen meslekte uzmanlığa 15. veya 16. yıllarında ulaştığını belirtmiştir:

"Hizmet yılı olarak bakarsak yirmi beş yıldan çok fazla bir hizmeti süresine sahibim. Dolayısıyla son on yılımı ustalık dönemi olarak niteleyebilirim."(KÖ5, Mülakat dökümü)

"Ustalık dönemi için ise yaklaşık son yedi yıldır ustalık dönemi olarak nitelendirilebilirim (Not: Katılımcı meslekteki 23. yılındadır). Ne kadar ustalık dönemidir? Bunda kıstas nedir o tartışıır ama ustalık kişiden kişiye değişebilir. Dersinize hâkimiyetten tutun da bana göre ustalık dönemi öğrencinin getirdiği soruyu ben çözebiliyorsam ve ona anlatabiliyorsam, çocuk da ben anladım diyorsa bana göre bu bir ustalıktr." (KÖ15, Mülakat dökümü).

Hâlihazırdaki mesleki deneyimi yirmi yılın altında olan öğretmenlerin çoğunluğu $(f=8)$ ise uzmanlık dönemlerinin meslekteki 9. ile 14. yıllarından itibaren başladığını belirtmişlerdir:

"Yetkin uzmanlık dönemim 10. yıldan sonra diyebilirim. Tamamen bir uzman oluyorsun. Yani şu anda 17. yılımı çalışıyorum ve ustalık dönemimdeyim diyebilirim." (KÖ18, Mülakat dökümü)

"9. yııımdan itibaren gerek alanımda gerekse de öğretmenlik anlamında coğrafyada tam anlamıyla usta olduğumu yani yetkin bir uzmanlığı yaşadığımı düşünüyorum (Not: katllımcı meslekte 15. Yılını çalışmaktadır). Çünkü şu anda artı hem alan bilgisine hâkimiyet hem müfredata hâkimiyet açısından ve kanun yönetmelikleri uygulama açısından zümre toplantısı, yıllık plan gibi herhangi bir sıkınt yaşayacağımı düşünmüyorum. Bu alanlarda kendimi uzman olarak görüyorum. Ayrıca öğrenci ile ilişkilerde öğrencinin bizden beklentileri nelerdir bizim onlara verebileceklerimiz nelerdir, bu açıdan da öğrenciyi tanıma anlamında kendimi usta olarak nitelendirebilirim." (KÖ22, Mülakat dökümü)

Görüldüğü gibi hizmet süresi daha fazla olan katlımcılar, kendi görüşlerine göre yetkin uzmanlık aşamasına

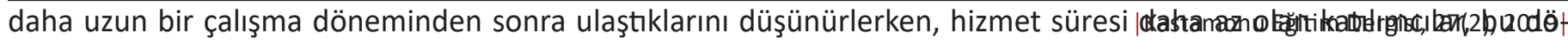


neme daha kısa bir çalışma döneminden sonra ulaştkklarını düşünmektedirler. Bu durum uzmanlık algısının objektif ölçütler yerine katılımcıların öz-yeterlik algılarıyla ilişkili olduğuna işaret etmektedir. Peki katılımcılar yetkin uzmanlığı nasıl değerlendirmektedir? Tablo 6 bu kapsamda katılımcıların verdiği yanıtları özetlemektedir.

\section{Tablo 6. Yetkin uzmanlık döneminin özellikleri}

\begin{tabular}{lc}
\hline Katılımcı görüşleri & Frekans \\
\hline Öğrencilerle daha yakında ilgilenmek & 9 \\
Zaman, emeği ve ders araç-gereçlerini daha verimli kullanmak & 7 \\
Alan bilgisi, öğretim programı, kanun ve yönetmeliğe hâkim olmak & 7 \\
Mesleki gelişmeleri öğretmen ağlarından veya sosyal medyadan takip etmek & 4 \\
Yaş ilerlediği için motivasyon ve enerjinin azalması & 4 \\
Sınav sisteminde yapılan değişiklikler sebebiyle motivasyondaki azalma & 3 \\
\hline Toplam & 36 \\
\hline
\end{tabular}

Tablo 6'da görüldüğü gibi, farklı hizmet süresine sahip olmakla birlikte, mesleklerinde yetkin uzmanlık dönemlerini yaşadıklarını belirten katılımcı öğretmenler, bu dönemin özelliklerine toplamda alt farklı nitelik dile getirmişlerdir. Bunlardan en dikkat çekeni, dokuz katılımcının yetkin uzmanlık dönemlerinde, öğrencilerle daha yakından ilgilendikleri, onları kendi evlatları gibi gördüklerini belirtmiş olmalıdır:

“Derse girdiğim zaman öğrencilerin yüz ifadelerinden psikolojik sıkıntıları olup olmadığını, özel bir problemleri olup olmadığını kesinlikle anlarım ve dersten sonra çağırıp kendisine sorarım: 'Bir derdin mi var? Nedir? Hayırdır?’ diye. Çünkü bu çocuklar hepimizin, bu gelecek hepimizin. Ben hep uzun vadeli düşünmeye çalıştım ve bu manada da hep olumlu dönütler aldım, emeğimin karşılığını aldığımı düşünüyorum." (KÖ1, Mülakat Dökümü)

"Ben artık öğretmenliğin yanında eğitmenlik yönümle öğrencilere bir anne gibi yaklaşarak model olmaya çalışıyorum." ( KÖ10, Mülakat Dökümü)

Katılımcılar tarafindan en çok dile getirilen ikinci unsur $(f=7)$, uzmanlığın "zamanı, emeği ve ders araç gereçlerini daha verimli kullanma" yeterliğinin gelişmiş olmasıdır:

"Uzmanlık benim için şudur; ilk yıllarda belki bir ayda anlatabildiğim bir konuyu öğrencilere şimdi bir derste iki derste anlatabildiğimi düşünüyorum. Çünkü artk gelen öğrencinin kapasitesini, neyi nasıl anlayabileceğini az çok biliyoruz." (KÖ2, Mülakat Dökümü)

"Bu dönem benim için öğretmenlik için her türlü araç gereci örneğin bilgisayarı, teknolojiyi, akıllı tahtayı en iyi şekilde kullandığım dönemdir. Ben her türlü teknoloji unsurunu ders materyali olarak derslerimde en iyi şekilde kullanırım." (KÖ24, Mülakat Dökümü)

Yetkin uzmanlık döneminde olduklarını belirten 25 coğrafya öğretmeninden yedisi, meslekteki son yıllarında alan bilgisi, öğretim programı, kanun ve yönetmeliğe hâkim olmalarının mesleki anlamda kendilerini uzman olarak hissetmelerine yol açtı̆ını düşünmektedirler:

"Yetkin uzmanlık benim için şu demek: Planlı programlı, hiç müfredata bakmadan, yıllık planlara bakmadan üniteleri hangi dönemde neyi işleyeceğimi bile biliyorum..." (KÖ20, Mülakat Dökümü)

"Şu anda artık hem alan bilgisine hâkimiyet hem müfredata hâkimiyet açısından ve kanun yönetmelikleri uygulama açısından zümre toplantısı, yıllık plan, gibi herhangi bir sıkıntı yaşayacağımı düşünmüyorum. Kendimi uzman olarak görüyorum." (KÖ22, Mülakat Dökümü)

“...uzmanlık açısından son yıllardaki derslerim sanki otomatiğe bağlamış gibi gitti. Şu anda hiçbir kaynağa gerek kalmadan her türlü lise konusunu anlatabilirim." (KÖ9, Mülakat Dökümü)

Katılımcılardan bazıları ( $f=4)$, yetkin uzmanlığı belirleyen en önemli niteliğin mesleki gelişim için meslektaş ağlarına (ve bu bağlamda sosyal medya gruplarına) üyelik olduğunu belirtmektedirler.

"Yetkin uzman bir öğretmen olarak, hem branş hem de pedagojik anlamda kendimi her yıl yenilemek istiyorum ve bu açıdan çalışmalar yapıyorum ama bunu yaparken herhangi bir dergi herhangi bir makale takip etmek gibi bir durum söz konusu değil, daha çok internetten; işte memurlarla ilgili bazı sitelerden, coğrafya öğretmenlerinin kurduğu bazı sitelerden ve Facebook gruplarından gelişmeleri takip etmeye çalı- 
Şıyorum." (KÖ5, Mülakat Dökümü)

Toplamda yedi katılımcı uzmanlığın bir bedel karşılığı geldiğini düşünmektedirler. Bu grup Tablo 6'da görüldüğü gibi kendi içinde ikiye ayrılmaktadır. Birinci grup olgunlaşmaya bağlı olarak yaşadıkları motivasyon kaybına dikkat çekerken, ikinci grup sınav sisteminde yapılan değişiklikler ve buna bağlı olarak coğrafyanın statüsünün azalmasına dikkat çekmektedirler. Illk grup katlımcılar yaşlarının getirdiği sağlık sorunları ile ailevi yükümlülükleri dile getirirken, ikinci grup katılımcılar, yaşlarının da etkisiyle, artık "havlu atma" eğilimi göstermektedirler. Çünkü bir katılımcının belirttiği gibi "eğer kimse coğrafyayı önemsemiyorsa, kendilerinde de artık bu zamandan sonra önemseyecek bir enerjileri kalmıyor".

"Meslekte artkk bir noktaya gelince, uzmanlaşınca, bu kez de yaş ilerlediği için motivasyon ve enerjide bir düşüş başlıyor. Gündemi takip etmede, coğrafya alanındaki yeni gelişmeleri takip etmede biraz isteksizlik meydana geliyor. Ayrıca, ailevi yükümlülükler de bu motivasyonsuzluk da etkili." (KÖ3, Mülakat Dökümü)

"Esasen kendimi uzman olarak hissetmeye başladığım şu son 4 yılda, öğretmenlikten de zevk almıyorum okuldan da zevk almıyorum. Sadece görevim olduğu için gidip yapıyorum. Ben coğrafya öğretmenliğine severek başladım, ama şu son dönemlerdeki coğrafya dersine olan ilginin ve bakış tarzının değişmesi, öğrencilerin disiplinsizleşmesi beni öğretmenlikten soğuttu. Son 4 yıl verimsiz dönem diyebiliriz." (KÖ19, Mülakat Dökümü)

\section{Meslekte öğretmenliği öğrenmek}

Verinin analizi sonucu elde edilen üçüncü tema, katılımcı öğretmenlerin nasıl birer yetkin bir uzman coğrafya öğretmeni oldukları ile ilişkilidir. Bu bağlamda verinin analizinde kariyerleri sürecinde mesleklerini (ve mesleki uygulamalarını) en çok kimlerden ya da hangi kaynaklardan öğrendikleri ön plana çıkmıştr. Tablo 7 incelendiğinde, katılımcıların usta bir öğretmen olarak gelişimlerinde, birden fazla etkenin söz konusu olduğu görülmektedir.

\section{Tablo 7. Öğretmenlik mesleğini kimden/nereden öğrendi?}

\begin{tabular}{lc}
\hline Katılımcı görüşleri & Frekans \\
\hline Kendi deneyimlerinden & 19 \\
Lise/üniversite eğitimi sırasında rol model alınan öğretmenlerden & 17 \\
Hizmet içi eğitim kurslarından & 6 \\
Okunan eserlerden & 4 \\
Zümrelerin paylaşth̆̆ı deneyimlerden & 3 \\
\hline Toplam & 49
\end{tabular}

Tablo 7'de görüldüğü gibi kathlımcıların öğretmenliği öğrenmelerinde iki temel faktör "kendi deneyimleri" ile "öğrencilik yıllarından rol model aldıkları öğretmenleri”dir. Bu iki madde bize, çalışmaya katılan öğretmenlerin, açık bir şekilde öğretmenliği bizzat yaşayarak ve taklit ederek öğrendiklerini göstermektedir. Aşağıda örneklendirildiği gibi katılımcılar, meslekte uzmanlaşmaları sürecinde en çok kendi deneyimlerine başvurmaktadır:

"Ben, öğretmenliği meslekte çalıştıkça öğrendim. Öğretmenlik bir süreç işidir, öğretmenliği yaparak ve yaşayarak öğreniyorum. Hâlâ da yeni şeyler öğreniyorum." (KÖ16, Mülakat dökümü).

"Ben öğretmenliği kendim, yıllar içinde öğrendim." (KÖ2, Mülakat dökümü)

Katılımcıların belirttiğine göre, öğretmenliği öğrenmenin en pratik ve somut yolu, kendi öğrencilik yıllarındaki öğretmenlerini taklit etmektir. Bu durumun öğretmenlik mesleğinin başlangıç aşamasında çok daha belirgin olduğu anlaşılmaktadır:

“Özellikle ilk yıllarımda başta annem ve babam olmak üzere hayatımdaki iyi öğretmenleri örnek aldım hep. Onlar nasıl yapardı sorusunu aklıma getirir ve ona göre uygulama yapardım." (KÖ9, Mülakat dökümü)

“Ben, lisede okurken öğretmenlerimizi hep gözlemledim. 'Ben öğretmen olsam şu öğretmen gibi olmak isterim, dersimi şu öğretmen gibi anlatırdım ya da tam tersi kesinlikle şu hocaya benzemek istemezdim, ben kesinlikle böyle yapmazdım' diye düşünürdüm. İşte şu anda onu yapmaya çalışıyorum." (KÖ5, Mülakat dökümü)

Öğretmenler, mesleğe başladıktan sonra görev yaparken de kendini yetiştirmeye ve kişisel gelişime ihtiyaç duyarlar. Esasen yetkin bir uzman öğretmen olma yolunda en etkili faktörlerden birisi, hizmet içi eğitimlerdir. Bu alanda, Milli Eğitim Bakanlığı, öğretmenleri imkânları ölçüsünde desteklemekte ve öğretmenlerin gerek bireysel kariyer gelişimleri için gerekse uygulamalardaki aksaklıkları gidermek için çeșitli kurslar ve seminerler düzenlemektedir. Nitekim katılım- 
cllardan altısı meslek hayatları boyunca aldıkları hizmet içi eg̈itimlerin kendilerini uzman bir öğretmen olma yolunda desteklediğini belirtmişlerdir. Bu altı katılımcının da ortak olarak dikkat çektikleri husus, aşağıda KÖ25'in sözleriyle örneklendirilmiştir:

“Öğretmenliğe başladığımdan itibaren yirmi üç yılın neredeyse son yirmi yılında ben, sürekli hizmet içi eğitim kurslarını takip ediyorum. Her türlü hizmet içi eğitim kurslarına katllıyorum ve özellikle son üç dört yıldır hizmet içi eğitim kurslarının çok faydalı olduğunu düşünüyorum." (KÖ25, Mülakat dökümü).

Son yıllardaki hizmet içi eğitim anlayışııın bir değişim geçirdiğini vurgulayan bu öğretmenler, etkinlik temelli ve uygulamaya yönelik hizmet içi eğitim anlayışının önemli öğretmenlik tecrübelerine rağmen kendilerine yeni mesleki beceriler edindirdiğini belirtmektedirler. Bununla birlikte hizmet içi eğitimlerin mesleki anlamda gelişimlerine katkı yapmadığını düşünen birçok katılımcı da mevcuttur ( $f=7)$. Bu katılımcıların birçoğu mesleki hayatları boyunca sadece birkaç hizmet içi eğitime katıldıklarını, çünkü coğrafya branşına yönelik kurs sayısının sınırlı olduğunu, mevcutların ise 'faydasız', 'amaca hizmet etmeyen' ve 'yetersiz' olduğunu belirtmişlerdir:

"Mesleki hizmet içi eğitim aldım ama coğrafya branşına özel bir hizmet içi eğitim almadım. Mesleki hizmet içi eğitimlerini ben, hiçbir zaman tasvip etmiyorum. Çünkü amaca hizmet etmiyor." (KÖ2, Mülakat dökümü).

“Coğrafya öğretmenlerine yönelik hizmet içi eğitim, hâlâ kontrol ediyorum, bakıyorum, çok fazla yok hatta hiç yok. Geçen sene Mersin'de Coğrafi Bilgi Sistemleri kursu vardı. Ona katıldım ama yetersizdi, hiçbir şey öğrenemedim açıkçası." (KÖ7, Mülakat dökümü)

Uzman öğretmen olma yolunda katılımcı öğretmenlerin başvurduğu diğer iki kaynağın ise "çeşitli eserler" ile "zümrelerin deneyimleri" olduğu görülmektedir. Ancak bu faktörler sırasıyla sadece dört ve üç öğretmen tarafindan dile getirilmiştir. Öğretmenlere mesleki gelişimleri için kaynaklık eden en önemli eserler; ders kitapları, dergiler ve internet siteleridir. Ancak bu kaynakların, öğretmenlerin mesleki becerilerinin gelişmesinden ziyade alan bilgilerine katkı yaptı̆ı anlaşılmaktadır:

"Bir dönem coğrafyaya geçtiğim yıllarda idealist düşünerek Atlas, National Geographic gibi dergileri alıp okudum, onların verdiği haritaları biriktirdim. Bu beni bilgi açısından oldukça geliştirdi." (KÖ9, Mülakat dökümü)

Sadece bir katılımcı pedagojik anlamda kendilerini geliştirmeye yönelik eserler de okuduğunu belirtmiştir:

“Özellikle öğretmenliğe ilk başladığım yıllarda Doğan Cüceloğlu'nun "Savaşçı" adlı kitabını ve bugünlerde Özgür Bolat hocanın "Beni Ödülle Cezalandırma" adlı kitabını sık sık okuyorum ve oradan da gerek öğretmenlik anlamında bir şeyler öğreniyorum diyebilirim." (KÖ24, Mülakat dökümü)

Genelde tüm meslektaşlarla özelde ise zümre ile gerçekleştirilecek işbirliği, mesleki gelişimde oldukça önemli olmakla birlikte, çalışmaya katılan yirmi beş öğretmenden sadece üçü zümrelerinin mesleki gelişimlerine yaptıkları katkıyı dile getirmişlerdir:

"Birlikte çalıştğımız zümre arkadaşlarım bana çok yardımcı oldu, sağ olsunlar, onların tecrübelerinden çok faydalandım." (KÖ15, Mülakat dökümü)

Bulgular, katılımcı öğretmenlerin mesleklerini oldukça izole bir anlayışla yürüttüklerini düşündürmektedir. Bu durum çoğu zaman mecburiyetten de kaynaklanmaktadır:

"Tek zümre çalışıyorum. Dolayısıyla bu benim için bir dezavantaj. Çünkü akıl akıldan üstündür derler, bir zümre arkadaşım daha olsaydı, onunla birlikte çalışıp en azından birlikte nasıl yaparız diye bir fikir paylaşımında bulunurduk ve bu benim gelişimime daha fazla katkı sağlardı, beni hızlandırırdı." (KÖ8, Mülakat dökümü)

“Tokat ve Kırşehir'de hep tek zümre olarak çalıştım. Dolayısıyla benim örnek alacağım bir zümrem yoktu.

Bu sebepten o dönemlerimi acemilik olarak düşünüyorum..." (KÖ14, Mülakat dökümü).

Bu sözlerden, okullarda, branşında tek kişi olmanın, işbirliğine dayalı çalışmaları yürütme potansiyeli olan öğretmenlere önemli bir ket vurduğu anlaşılmaktadır.

\section{Tartışma, sonuç ve öneriler}

Tüm mesleklerde olduğu gibi öğretmenlikte de profesyonellik yolunda kariyer basamaklarını başarılı bir şekilde çıkmak önemlidir (Day, 1999). Eğer bu süreç Huberman (1995)'nın belirttiği gibi “Keşfetme - deneyimsel uyarlamalar yapma ve sınıf içi etkinlikleri çeşitlendirme - huzurlu bir şekilde uzmanlığın tadını çıkarma - dingin bir şekilde mesleğe yönelik ilgi ve kaygılarını azaltarak emekli olma" şeklinde gerçekleşirse, motivasyon ve profesyonel uygulamalar bakı- 
mından ideal olan bir meslek yaşantısı ortaya çıkacaktır. Ancak mesleğe yapılan zor başlangıçlar ve devam eden süreçte meydana gelebilecek sorgulamalar ve tutucu uygulamalar bir öğretmenin huzursuz ve verimsiz bir şekilde mesleği yapmasına yol açabilecektir (Huberman, 1995).

Fessler (1995)'in belirttiği gibi bir kişinin öğretmenliğe nasıl başladığı onun kariyerinin ilerleyen dönemlerindeki algı ve uygulamalarını etkileyen faktörlerdendir. Çalışmada elde edilen bulgulara göre, katılımcıların birçoğu mesleğe çok kolay bir başlangıç yapmamışlardır. Bunun temel sebepleri arasında ilk sırayı sınıf yönetimi bakımından yaşadıkları tecrübesizlik almaktadır. Mesleğe genel öğretmenlik yeterliklerinin tam olarak gelişmediği bir dönemde giriş yapan öğretmenlerin bu süreçte genellikle ilgili literatürde de belirtildiği gibi "hayatta kalma" stratejisi güttükleri görülmektedir (bkz. Huberman, 1995). Çünkü bu süreçte ihtiyaç duydukları desteği yeterince alamamışlardır. Öğretmenliğin ilk yıllarındaki karşılaşılan zorlukların bir diğer sebebi de katılımcıların coğrafya alan bilgisine tam olarak hâkim hissetmemeleri ile ilişkilidir. Bu bağlamda çalışmaya katılan birçok öğretmen meslekteki acemilik yıllarını lise 1, 2 ve 3 coğrafya konularına hâkim olabilmek ve kendilerini geliştirmek için harcadıklarını belirtmişlerdir. Esasen ortaya çıkan en temel bulgulardan birisi katılımcıların ders çalışarak geçirdikleri yılları acemilik dönemleri olarak nitelendirmeleridir. Bu süreçte kendilerini geliştirmek adına ağırlıklı olarak yapılan şey ise alan bilgisine (coğrafya konuları) yönelik çalışmaktır. Bu dönemde alan eğitimi bağlamında kendisini geliştirerek farklı yöntem ve teknikler konusunda ustalaşmaya çalıştı̆ını belirten katılımcı sayısı çok azdır. Oysa Karabağ (2007)’ın belirttiği gibi coğrafya öğretmenlerinin mesleki niteliğini belirleyen temel faktörlerden birisi de coğrafya öğretim bilgisidir. Bu kapsamda öğretim program bilgisinin yanı sıra, coğrafyanın öğrencilere etkili bir şekilde aktif öğrenme yöntemleriyle öğretilmesi gerektiğine vurgu yapılmaktadır (Karabağ, 2007). Ancak çalışmanın bulgularına göre acemilik dönemlerinde katılımcıların coğrafya öğretimine dair yeterliklerini artıracak meslektaş dayanışması, iş birliğine dayalı bir okul kültürü ve mentörlük gibi destek mekanizmaları genellikle söz konusu olmamıştır. Katılımcıların yarısından çoğunun belirttiğine göre öğretmenliği süreç boyunca kendi deneyimleri ile (el yordamıyla) öğrenmişlerdir. Mesleğinin ilk yıllarını sınıf içi uygulamalardan bağımsız olarak daha çok sosyo-ekonomik zorunluluklar bağlamında betimleyen katılımcılar da olmuştur. Bu kapsamda, ekonomik zorluklar nedeniyle dershanede çalışmak, çocukların sorumlulukları ve çalışılan bölgedeki güvenlik kaygılarının hayatın merkezine oturması konuları dile getirilmiştir.

Acemilik döneminde öğretmenliğin nasıl yapılması gerektiğine dair uygulamalarda katılımcıların önemli bir bölümü, rol model aldıkları eski bir öğretmenlerini referans göstermiştir. Bu durumda mesleğin ilk yıllarında öğretmenlik becerilerinin çoğu zaman taklit yoluyla hayata geçirildiği belirtilebilir. Başka bir ifadeyle katılımcı öğretmenlerin birçoğunun öğrencilik hayatının şu ya da bu döneminde öğretmeni olmuş, sevdiği bir kişiyi model olarak benimseyen ve onun gibi olmaya çalışan bir acemilik dönemi geçirdikleri görülmektedir. Üniversiteyi bitirdikten sonra kendisini çoğu zaman önceki hayatında hiç de karşılaşmadığı bir ortamda bulan genç öğretmenin imdadına kendi idolü olan öğretmenleri taklit etmenin yetiştiği görülmektedir. Ancak bu durum her zaman avantaj değildir. Çünkü, öğretmenin kendisini yenilemesine engel oluşturabilmektedir. Nitekim bir öğretmenin mesleğe başlamadan önce binlerce saat başka öğretmenleri gözlemlediğini belirten Öztürk (2014, s. 991), şu şekilde devam etmektedir:

.... [Bu öğretmenler] mesleğe başladığında hatta çoğu zaman eğitim fakültesine girdiğinde kafasında ideal öğretmeni oluşturmuş durumdadır. Eğer, bir öğrencinin seneler boyunca dersine giren öğretmenleri temelde aynı mantık çerçevesinde hareket etmişse... ve tek önemli fark bazı öğretmenlerin güler yüzlü diğerlerinin soğuk oluşu ise mesleğe yeni başlayan bir öğretmenin öğretmenliğe dair sahip olacağı inançları da [klasik anlayış tarafindan] şekillendirilmiş olacaktır.

Böylesi bir durum yıllarca değişmeden, yenilenme ihtiyacı duyulmadan, hep aynı yol, yöntem ve bilginin sürekli tekrarlanması sonucunu doğurmaktadır. Çünkü öğretmenler diğer tüm profesyoneller gibi alışkanlıklarının esiri olma eğilimi gösterirler. Türkiye'deki birçok sınıfa yapılacak ziyarette, kullanılan öğretim yöntemleri bakımından karşılaşılacak manzaranın anlatım ve soru-cevap yöntemi ile sınırlı kalacağı düşünülürse, bu durumun yaratacağı tahribat daha iyi kavranabilir (Öztürk ve Mutlu, 2017). Hâlbuki öğretmenlik mesleği en dinamik, en fazla değişkeni olan meslekler arasında yer almaktadır; çünkü okullara gelen her nesil yeni bir anlayış ve değişimi gerektirmektedir.

Öğretmenliği öğrenme ve tecrübe arasındaki doğrudan ilişki, bizi, öğretmenlerin kariyerlerinin hangi aşamasında neyi nasıl yaptıkları ve öğrendikleri sorusunu sormaya itmektedir. Tecrübeli birçok öğretmenin üzerinde hem fikir olacağı gibi, "öğretmenler dünyanın neresinde olursa olsun öncelikle ve çoğunlukla yaşadıkları tecrübeler sayesinde öğretmeyi öğrenirler" (Day, 1999, s. 49; Day, Sammons, Stobart, Kington \& Gu, 2007). Nitekim bu çalışma sonucunda ortaya çıkan en önemli sonuç öğretmenlerin mesleklerini çoğunlukla kendi kendilerine tecrübe ederek öğrendikleridir. Bu bulgu uluslararası literatüre uyum sağlamaktadır (Hargreaves, Lieberman, Fullan, \& Hopkins, 2010; Day, 1999). Ancak iş birliğine dayalı bir okul kültürü, zümre ve meslektaşlar arasındaki işbirliği ve etkili mentörlük gibi uygulamaların öğretmenlerin daha kısa zamanda daha yetkin olmalarını katkı sağladığı bilinmesine karşın, bu çalışmada elde edilen bulgular Türkiye şartlarında öğretmenlerin bu tür destek mekanizmalarından mahrum kaldıklarını 
Öztürk (2014), öğretmenliği yukarıda açıklandığı şekilde bizzat kendi gözlemleriyle ve genellikle klasik bir eğitim anlayışından hareketle öğrenen öğretmenlerin, kariyerleri boyunca klasik eğitim anlayışını sürdürdüklerini, bunun da çoğunlukla geriye döndürülemediğini savunmaktadır. Bu süreçte etkili olarak kullanılabilecek araçlardan bir tanesi hizmet içi eğitimlerdir. Eğer iyi organize edilirlerse ve öğretmenlerin sürekli mesleki gelişimi bağlamında ele alınırsa hizmet içi eğitimlerin sınıf içi uygulamalara olumlu şekilde yansıdığı bilinmektedir (OECD, 2016; Günel \& Tanrıverdi, 2014.). Ancak bu çalışmaya katılan öğretmenler, meslek hayatları boyunca katıldıkları yerel ya da merkezi hizmet içi eğitim seminerlerini / kurslarını gerek coğrafya branşı ile ilgili olanlarının az sayıda olması gerek de verimsizliği açısından eleştirmişlerdir. Esasen meslek hayatı boyunca öğretmenlik becerilerinin gelişimine en az etki eden faktörün hizmet içi eğitimler olduğu görülmektedir.

Öğretmen eğitiminin iki temel aşamasını hizmet öncesi eğitim ile hizmet içi eğitim oluşturur. Hizmet öncesi eğitim genellikle maksimum dört yıllık bir süreyi kapsarken, hizmet içi eğitim kişinin emekli oluncaya kadarki dönemini kapsar. Güncel gelişmelerin takip edilebilmesi, yeni bilgi ve becerilerin kazanılabilmesi için önemli olan hizmet içi eğitimlere katılımın mesleki gelişim açısından öneminin ve faydasının sadece üç katılımcı tarafindan önerilmesi dikkate değerdir. Bunun temel sebebi muhtemelen hizmet içi eğitimlere karşı öğretmenlerin takındığı olumsuz tutumdur. Esasen bu olumsuz tutumu besleyen de etkili olmaktan uzak hizmet içi eğitim uygulamalarıdır. Hâlbuki etkili hizmet içi eğitimler öğretmenlerin taklitten özgünlüğe geçişini sağlayabilir. Bilimselliği belirsiz deneyimler yerine akademik anlamda olsun, uygulama bakımından olsun daha sistematik yöntem ve tekniklerle öğretmeni buluşturabilir.

Bu olumsuz bakış açısı ve nitelendirmeler öğretmenlik mesleğinin başarısı bakımından ümit kırıcıdır. Zira öğretmenlerin mesleki gelişimlerinin uzun soluklu devam edebilmesi için işbaşındayken eğitilmelerinin de devam etmesi kaçınılmaz bir gerekliliktir (Day vd., 2007; Karip, 2018; Öztürk ve Eroğlu, 2013; Öğretmen Strateji Belgesi, 2017; Smylie, 1995). Zaten mesleğinde 15-20 yılı geride bırakanların yani yetişkin olanların eğitimlerinde pek çok zorluklar yaşanmakta iken hizmet içi eğitimlerin yetersizliği gibi olumsuzluklar hiç olmamalıdır. Kendilerini uzman kabul eden öğretmenlerin yenilikleri kabul etmeleri, bunlara uyum sağlamaları ve hatta kendilerini değiştirmeleri nasıl gerçekleşecektir?

Yetişkinlerin öğrenmesiyle ilgili araştırmalara baktığımızda farklı teoriler olmasına karşın, nispeten tutarlı bazı prensiplerden bahsetmek mümkündür. Yetişkinler en genel olarak yaşadıkları probleme çözüm oluşturacak ve uygulamaya doğrudan yansıttlabilecek öğrenmeleri önemserler (Smylie, 1995). Schein (1988)'nün bireysel değişim modeline göre ise, öğrenmenin gerçekleşmesi için, mevcut davranış ve tutumları destekleyen bilişsel-psikolojik dengeler "çözülme" ye uğramalıdır. Başka bir ifade ile kişinin, öncelikle sahip olduğu bilgi ve tutumun mevcut problemi çözmek için esasen yeterli olmadığının farkına varması gerekir. Bir kişi ortaya çıkan problemi çözmek için yeni bilgi veya beceriye ulaşmak isteyecektir ki, bu bilgi ve becerinin kaynağı çok çeşitli olabilir. Bu anlayış Smylie (1995, s. 94)'nin de belirttiği gibi yapılandırmacı bir öğrenme yaklaşımını yansıtır ve buna bağlı olarak yetişkin öğrenimi ile ilgili şu önermeleri sunar:

- Doğru yöntemlerin işe koşulması şartyla her yaştan insan yaşamları boyunca öğrenebilir,

- Yetişkin öğrenmesi her şartta ve her ortamda gerçekleşebilir,

- Yetişkinler de çocuklar gibi diğer akranlarıyla gerçekleştirdikleri etkileşimlerle daha hızlı öğrenebilirler,

- Yetişkinlerin önceki bilgileri ve yaşantısal tecrübeleri şimdiki öğrenmelerine büyük ivme kazandırır.

Esasen Dewey'e (1938, aktaran Smylie, 1995) göre, öğrenme, bireyin yaşadığı ikilem, sorun veya hissettiği belirsizlik arz eden güç durumlarda başlar. Birey bu sorunu önce tanımlar ve daha sonra alternatif çözümler ile analiz eder. Analizler, anlama ve belirli bir çözüm üzerinde hareket etme ya da harekete geçme kararına yol açan gözlem ve deneyleri içerebilir. Argyris (1993) yetişkin ve bu bağlamda öğretmen eğitiminde çift döngülü öğrenme (double-loop learning) yaklaşımından bahseder. Schön (1983)'nün yansıtıcı düşünme pratiğini de içeren bu yaklaşımda genelde yetişkinler özelde ise öğretmenler, bilgi birikimleri ve uygulamalarından oluşan ilk döngüyü (single loop learning), ancak bu döngünün dışına adım atıp kendi uygulamaları üzerine gerçekleştirdiği sorgulayıcı ve yansıtıcı düşünmeden oluşan ikinci döngü (second loop learning) ile kırabilir/geliştirebilir. Bu bağlamda Argyris ve Schön (1978) öğrenmenin, problemlerin kaynağına odaklanarak deneme-yanılma yoluyla, bir uygulayıcının her zamanki (sıradan) koşulları altında gerçekleştiğini belirtirler.

Çalışmanın bir diğer önemli boyutunu da katılımcı öğretmenlerin kariyer gelişim aşamalarının tespiti oluşturmaktadır. Huberman (1995)'ın kariyer çevriminde öğretmenlerin 7-18 yılları arasında profesyonel platoya ulaştıkları belirtilmektedir. Bu dönem öğretmenlerin öz-yeterliklerinin geliştiği bir süreç olup, çeşitli durumlara karşı inisiyatif geliştirecekleri ve olaylar karşısında kendi özgün tutumlarını sergileyebilecekleri bir dönemdir. Huberman öğretmenlikte 20-40. yılların tam anlamıyla uzmanlık aşaması olduğunu belirtir. Çalışmada elde edilen bulgulara göre katılımcılar çoğunlukla meslekteki 9.-16. yıllar arasında kendilerini uzman birer öğretmen olarak nitelendirmeye başladıklarını belirtmişlerdir. Katılımcıların uzmanlık algısı, çoğunlukla konu alanı bilgisi ve sınıf yönetimi bakımından | Kastamonu Eğitim Dergisi, 27(2), 2019| 
tam anlamıyla kendilerini yetkin hissetmeleriyle ilişkilidir. Bu dönemde katılımcıların, öğrencilerine karşı daha şefkatli yaklaştıkları, öğretim programına bağımlılıklarının azaldığı ve teknolojiyi daha çok pratik bilgiler edinmek için kullanmaya başladıkları görülmektedir.

Çalışmaya katılan öğretmenler tüm dünyada olduğu gibi, meslekteki ilk yıllarının acemilikle ve mesleği tanımakla geçtiğini belirtmişlerdir. Bu çalışmaya katılan coğrafya öğretmenlerinin kariyer süreçlerinde çeşitli aşamalardan geçtikleri açık bir şekilde görülmekle birlikte bu aşamaların süresi tam olarak uluslararası literatürde belirtildiği şekilde gerçekleşmemektedir. Çalışmanın bulgularından hareketle, çalışmaya katılan coğrafya öğretmenlerinin kariyer gelişimleri kendi görüşlerinden hareketle aşağıdaki şekildedir;

Acemilik dönemi: Mesleğin genellikle ilk 3-5 yıl arasındaki dönemi kapsamaktadır. Bu dönem katılımcı öğretmenlerin daha çok rol model aldıkları başka bir öğretmeni/öğretmenleri taklit ettikleri dönemdir. Bu süreci net bir şekilde belirleyen husus ise coğrafya konu alanına yönelik kendini geliştirme süreci olarak nitelendirilmiş olmasıdır. Bu süreçte zümre, meslektaş ya da hizmet içi eğitimlerden yeterince destek alınamadığı ise açık bir şekilde belirtilmiştir.

Uzmanlığa geçiş dönemi: Mesleğin yaklaşık 6. ila 14. yılları arasındaki dönemdir. Bazı çok temel bilgi ve uygulamalarda basit hataların yapılmadığı, bir taraftan konusuna göre kendi kendine yetmenin hazzı yaşanırken diğer taraftan da seçici okumalarla olgunlaşmanın gerçekleştiği dönemdir. Yani bu dönem öğretmenler için özgünleşme dönemidir. Bu arada, yuva kurma ve özel hayata yönelik işlere ağırlık verme, öğretim işlerinin yanında yürütülmeye çalışılmaktadır. Ancak özellikle bayan öğretmenler için özel hayat mesleki kariyer uğraşlarına daha baskın geldiği için kariyer gelişimleri sekteye uğrayabilmektedir.

Uzmanlık dönemi: Genellikle mesleğin 15. ve 16. yılından itibaren katılımcı öğretmenler yetkin uzmanlık aşamasına eriştiklerini, başka bir ifade ile tam olarak profesyonelleştiklerini belirtmektedirler. Bu dönemde, katılımcıların kendilerini yetkin bir uzman olarak nitelendirmelerinin temel sebepleri; sınıfa, alana, öğretim programı ve mevzuata hâkimiyet olarak dile getirilmiştir. Bu dönem, bazı öğretmenler için, rutin ve dinginlik dönemi olarak da nitelendirilebilecekken, bazıları için motivasyon ve enerji kaybının yaşandığı bir dönem olarak görülmektedir.

Her ne kadar araştırmaya katılan öğretmenler, sırasıyla acemilik, uzmanlığa geçiş ve uzmanlık dönemlerini geçmişlerse de yetkin uzmanlığın (profesyonelleşme aşaması) gerektirdiği özellikleri tam olarak yansıttkları söylenemez. Day (1999)'in Dreyfus'tan uyarladığına göre, [yetkin] uzmanlık dönemi, analitik sezgisel dönemdir ve öğretmenler bu dönemde işlerini daha iyi yapmak için sürekli bir arayış içerisinde olmalıdırlar. Dolayısıyla profesyonel anlamda yetkin uzmanlığın meslekteki hizmet yılıyla ilişkisi olmakla birlikte, sadece belli bir süre çalışan insanların yetkin bir uzman öğretmen olmaları söz konusu değildir. Çalışmaya katılan öğretmenlerin tümü on beş yılı aşkın mesleki tecrübeye sahipken, çoğunluğunun kendilerini geliştirmek adına önemli çabalar göstermedikleri görülmektedir. Esasen “öğretmenlerin devlet memuru olarak görüldüğü ve merkeziyetçi bir yapının hâkim olduğu Türkiye gibi ülkelerde, öğretmenin başlangıçta hayatta kalmak için yaptığı uygulamalar zaman içinde onun alışkanlığı ve dahi inancı haline gelmektedir" (Öztürk, 2014, s. 991). Böyle alışkanlıklar kazanmış olan öğretmenlerin yeni şeyleri nasıl öğrenecekleri, hatta nasıl değişecekleri önemli bir sorudur.

Profesyonel gelişim çabaları, mümkün olduğunca geniş bir vizyona dayanan uzun vadeli hedeflerle tasarlanmalıdır. Örneğin, bir öğretmenin profesyonel gelişimi için oluşturacağı stratejik planlamada şu hususlara dikkat edilmelidir: Takım çalışmasına önem vermek, öğrenme çıktılarıyla ilgili hesap verebilir olmak, öğrencinin gelişimini sürekli takip etmek ve çağdaş öğretim anlayışını kendi çalışmalarına entegre etmek (Fullan, 2015; Louis \& Miles, 1990). Profesyonel gelişimde daha büyük başarıların anahtarı, yeni bilginin keşfedilmesinden ziyade sahip olunan bilginin yansıtıcı düşünme uygulamaları aracılığı ile sorgulanması ve geliştirilmesi kapasitesiyle ilişkilidir (Guskey, 1995). Bu kapasite, öğrencilerin farklı öğrenme gereksinimlerini gözetmek için devamlı olarak daha iyi yollar arayan ve sürekli mesleki gelişim içinde olan öğretmenlerde bulunur (Guskey, 1995; 126).

Gerçekleştirilen tartışma ve elde edilen sonuçlar bağlamında ulaşılan önerileri şu şekilde sıralamak mümkündür:

- Öğretmen adaylarının mesleği bilinçli olarak seçmelerine yönelik tedbirler alınmalıdır. Sevilen bir ya da birkaç öğretmenin hatırasından veya aile etkisiyle değil, gerçekten bu meslek istendiği ve yapabileceği için seçilmelidir. Mesleğe yeterince yüksek bir motivasyonla başlamayan, kariyerin sonraki süreçlerinde de yeterince destek almayan öğretmenlerin mesleki gelişime yönelik tutumları nispeten daha olumsuz olabilmektedir.

- Mesleğe yeni başlayan öğretmeni, meslektaşlarıyla işbirliğine açık, kendisini yenilemeye hazır ve sürekli öğrenmeye hevesli olmaya teşvik edici tedbirler alınması gerekmektedir. Bu süreçte onları destekleyecek mekanizmalar kurulmalıdır.

- Katılımcıların uzmanlığı çoğunlukla alan bilgisi ve sınıf yönetimi becerileri ile ilişsilendirdiği düşünülürse, yetkin uzman öğretmenlerden beklenen diğer becerilerin (alan eğitimi becerileri, analitik ve yansıticı düşünmeye dayalı bir uygulama gibi) geliștirilmesine yönelik bilinç geliștirmeye yönelik çalıșmalar yürütülmelidir. 
Hizmet içi eğitimler, ögretmenleri yetkin uzman olma süreçlerinde desteklemek için onların yoğun mesaisinde ulaşamadığı bilgiyi, beceriyi ve donanımı en hızlı, en kolay ve en kapsamlı şekilde elde etmesine yardımcı olacak yöntem ve tekniklere göre düzenlenmelidir.

\section{Kaynakça}

Argyris, C. (1993). On organizational learning. Cambridge, MA: Blackwell.

Argyris, C., \& Schön, D. (1978). Organizational learning: A theory of action perspective. Reading, Mass: Addison Wesley.

Ayress, L. (2008). Semi-structured interview. In Lisa M. Given (Eds.) The sage encyclopedia of qualitative research methods. California: The Sage.

Darling-Hammond, L. (2008). Teaching and the change wars: the professionalism hypothesis. In Hargreaves, A. \&Fullan, M. (Eds.) Change wars. Bloomington: Solution Tree.

Day, C. (1999). Developing teachers: The challenges of lifelong learning. London: Falmer Press.

Day, C., Sammons, G., Stobart, A., Kington, \& Gu, Q. (2007). Teachers matter: Connecting work, lives and effectiveness. London: Open University Press.

Dean, J. (1991). Professional Development in School. Buckingham: Open University Press.

Dreyfus, S. E., \& Dreyfus, H. L. (1980). A five-stage model of the mental activities involved in directed skill acquisition. Unpublished report, University of California, Berkeley.

Fessler, R. (1995). Dynamics of teacher career stages. In Thomas R. Guskey and Michael Huberman (Eds.) Professional development in education. New York: Teachers College Press.

Fessler, R. and E. Rice. (2010). Teachers career stages and professional development. In P. Peterson, E. Baker, and B. McGaw (Eds.) International Encyclopedia of Education, 582-586. Oxford: Elsevier.

Fullan, M. (2015). The new meaning of educational change ( $5^{\text {th }}$ edition). New York: Teachers College Press.

Guskey, T. (1995). Professional development in education: In search of the optimal mix. In Thomas R Guskey and M. Huberman (Eds.) Professional development in education new paradigms \& practices. New York: Teachers College Press.

Gümüş, N. \& Çapar, T. (2011). Coğrafya öğretmenliği bölümü öğrencilerinin öğretmenlik mesleğine yönelik tutumları. International Online Journal of Educational Sciences, 3(1), 395-410

Günel, M \& Tanrıverdi, K. (2014). Dünya'da ve Türkiye'de hizmetiçi eğitimler: kurumsal ve akademik hafıza (kayıpları)mız. Eğitim ve Bilim, 39(175), 73-94.

Güven, İ. (2004). Sosyal bilgiler alanı öğretmen adaylarının okul uygulamalarına yönelik görüşleri üzerine nitel bir araştırma. Kuram ve Uygulamada Eğitim Bilimleri, 4(2), 271-300.

Hargreaves, A. (2000). Four ages of professionalism and professional learning. Teachers and Teaching, 6(2), 151182, DOI: $10.1080 / 713698714$

Hargreaves, A., Lieberman, A., Fullan, M. \& Hopkins, D. (2010). Introduction. In Hargreaves, A., Lieberman, A., Fullan, M. \& Hopkins, D. (Eds.) Second international handbook of educational change. Dordrecht: Springer.

Hargreaves, A. \&Fullan, M. (2012). Professional capital: Transforming teaching in every school. New York: Teachers College Press.

Huberman, M. (1995). Professional careers and professional development: Some intersections. In Thomas R. Guskey and Michael Huberman (Eds.) Professional development in education. New York: Teachers Collage Press.

Miles, M. \& Huberman, A. M. (1994). An expanded sourcebook qualitative data analysis ( $2^{\text {nd }}$. Edition). London: Sage

Karabağ, S. (2007). Coğrafya öğretmenlerinin mesleki sorumlulukları (271-287). Karabağ, S. \& Şahin, S. (Eds.) Kuram ve uygulamada coğrafya eğitimi. Gazi Kitapevi, Ankara.

Karademir, N. (2012). Coğrafya öğretmen adaylarının mesleki yeterliklerine yönelik hazırbulunuşluk düzeyleri, Doktora tezi, Gazi Üniversitesi, Ankara.

Karip, E. (2018). 2017 eğitim değerlendirme raporu. Ankara: TED Yayınları

Kılınç, A. Ç. (2014). School culture as a predictor of teacher professionalism. Education and Science, 39(174), 105-118.

Little, J. W. (2012). Professional community and professional development in the learning-centered school. In M. Kooy and K. Van Veen (Eds.) Teacher learning that matters: International perspectives. London: Routledge.

Louis, K. S., \& Miles, M. B. (1990). Improving the urban high school: What works and why. New York: Teachers College Press.

Monika L. L., Klaas van V., Jacobiene A. M. \& Jan H. van D. (2017). Teachers' professional learning goals in relation to teaching experience, European Journal of Teacher Education, 40(4), 487-504.

Mourshed, M., Chijioke, C. \& Barber, M. (2010). How the world's most improved-school systems keep getting better? MacKinsey \& Company için oluşturulmuş rapor. Erişim Tarihi (05.10.2018): https://www.mckinsey.com/industries/social-sector/our-insights/how-the-worlds-most-improved-school-systems-keep-getting-better

OECD (2016). Teacher professionalism. Teaching in Focus, No. 14, OECD Publishing, Paris, https://doi.org/10.1787/5jm3xgskpc40-en.

| Kastamonu Eğitim Dergisi, 27(2), 2019| 
OMGY(2017). Ogretmenlik mesleği genel yeterlikleri. Ankara: Ogretmen Yetiştirme ve Geliştirme Genel Müdürlügü. (Erişim tarihi: 25.09.2018):

http://oygm.meb.gov.tr/meb iys dosyalar/2017 12/11115355 YYRETMENLYK MESLEYY GENEL YETERLYKLERY.pdf

ÖSB (2017). Ulusal öğretmen strateji belgesi. Ankara: Öğretmen Yetiştirme ve Geliştirme Genel Müdürlüğü. (Erişim tarihi: 25.09.2018):

http://oygm.meb.gov.tr/meb iys dosyalar/2017 06/09140719 Strateji_Belgesi_Resmi_Gazete sonrasY ilan.pdf

Özder, A. (2014). Coğrafya öğretmenlerinin meslek tercihlerinde lise coğrafya öğretmenlerinin etkisi üzerine bir çalışma, SDU International Journal of Educational Studies, 1, 54-62.

Öztürk, M. (2014). Coğrafya eğitiminde araştırma, Ankara: Pegem Yayınları.

Öztürk, M \& Eroğlu, E. (2013). Coğrafya öğretmen yeterlikleri ve uygulamaların değerlendirilmesi, Marmara Coğrafya Dergisi, 27, 630-659.

Öztürk, M. ve Mutlu, N. (2017). Farklılaştırılmış, beceri ve değer temelli öğretim: kavramsal çerçeve. Öztürk, M. ve Saydam, A. (Eds.) Yenilikçi sosyal bilgiler ve tarih öğretimi: Teori ve uygulama. Kayseri: Orka.

Perera, H. N., Granziera, H. ve Mcllveen, P. (2018). Profiles of teacher personality and relations with teacher self-efficacy, work engagement, and job satisfaction. Personality and Individual Differences. Vol. 120, 171-178.

Schein, E. H. (1988). Organizational psychology (3 ${ }^{\text {rd }}$ edition). New Jersey: Prentice-Hall

Schön, D. (1983). Reflective practitioner: How professional think in action. New York: Basic Books.

Sternberg, R. J., \& Horvath, J. A. (1995). A prototype of expert teaching. Educational Researcher, 24, 9-17.

Townsend, T \& Bates, R. (2007). Handbook of teacher education. Dorsrecht: Springer.

Villegas, R. E. (2003). Teacher professional development: An international review of the literature, Unesco: IIEP.

Yıldırım, A. \& Şimşek, H. (2016). Sosyal bilimlerde nitel araştırma yöntemleri. Ankara: Seçkin Yayıncılık. 